\title{
Administrative Law Enforcement, Warnings, and Transparency
}

\author{
DELCIANNA J. WINDERS*
}

Warnings are one of the primary ways that administrative agencies enforce the law. Yet there is virtually no scholarship interrogating the role that warnings play in an agency's arsenal. Are they effective in motivating compliance? If so, under what circumstances? Is reliance on warnings warranted at all? This Article tackles these important but overlooked questions.

Economic models of public enforcement suggest that warnings have no role in motivating compliance. Published data on the effectiveness of warnings is virtually nonexistent. Yet, in an apparent act of faith, administrative agencies rely heavily on warnings-often as their primary enforcement mechanism. This Article scrutinizes this use of warnings, through both a theoretical assessment and a case study of their efficacy in one particular context-the Federal Animal Welfare Act. After showing that warnings issued under the Animal Welfare Act frequently fail to incentivize compliance, the Article then assesses why this might be and discusses the implications of this failing for the many administrative agencies that rely on warnings. It also makes policy recommendations for improving the efficacy of warnings, including recommendations about disclosure that are especially timely given recent moves by the federal government to delete thousands of enforcement-related records from its websites.

"Laws without enforcement are just good advice." -attributed to Abraham Lincoln 1

"[A] threat has no deterrent value unless it is credible that it will be carried out...."

-Friends of the Earth, Inc. v. Laidlaw Environmental Services (TOC), Inc., 528 U.S. 167, 186 (2000).

${ }^{*}$ Vice President and Deputy General Counsel for Captive Animal Law Enforcement at the People for the Ethical Treatment of Animals (PETA) Foundation, and Visiting Scholar at the Elisabeth Haub School of Law at Pace University. The author would like to thank Cass R. Sunstein, Robert A. Kagan, Jacob E. Gersen, Barry Friedman, Katrina M. Wyman, Jessica Eisen, Kristen A. Stilt, Mark Lee, and Erin King. The Article also benefited from feedback at the Stanford Program in Law and Society's Third Conference for Junior Researchers, the Searle Center's Second Annual Research Roundtable on Animal Law and Regulation, and the Canadian Law and Economics Association's Annual Conference.

I John C. Cruden, Assistant Attorney Gen., U.S. Dep't of Justice, Remarks on Combating Wildlife Trafficking at the International Union for Conservation of Nature World Conservation Congress (Sept. 2, 2016), https://www.justice.gov/opa/speech/assistant-attomeygeneral-john-c-cruden-delivers-remarks-combating-wildlife-trafficking [https://perma.cc/DF535Q34]. 


\section{TABLE OF CONTENTS}

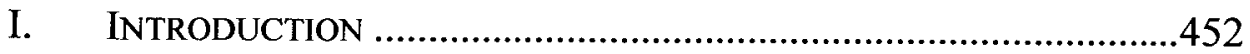

II. WARNINGS AND ADMINISTRATIVE ENFORCEMENT ......................458

A. The Prevalence of Administrative Warnings ........................458

B. Theorizing the Role of Warnings ..........................................461

1. Warnings Under the Traditional Model of Economic Enforcement.

2. Socio-Legal Studies, Responsive Regulation, and the Turn Away from a Strict Economic Model 462

C. Paucity of Empirical Data on the Efficacy of Warnings ......470

III. THE ANIMAL Welfare ACT.

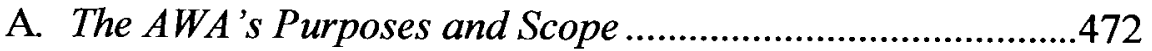

B. AWA Standards, Certification, and Inspections ....................473

1. Animal Welfare Standards .............................................473

2. Certification Under the AWA .........................................474

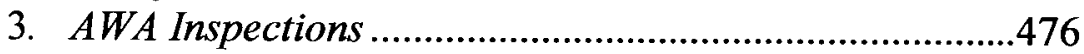

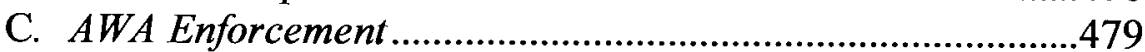

1. Statutory Provisions Pertaining to Enforcement ............479

2. AWA Enforcement Practices...........................................481

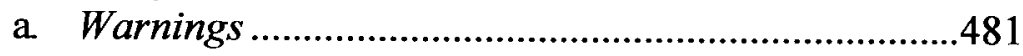

b. Settlement Agreements ...............................................483

c. Formal Administrative Proceedings ..........................486

d. Judicial Enforcement ...............................................487

IV. Case Study: ANIMAL Welfare Act Warnings AND

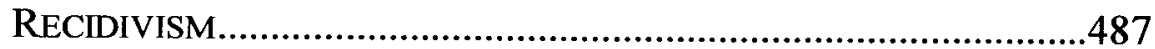

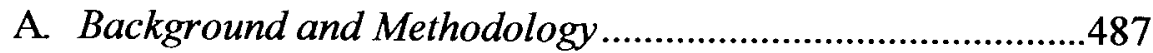

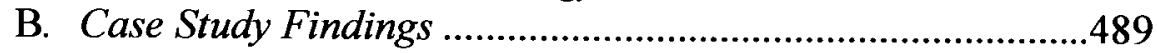

1. Rates, Types, and Examples of Recidivism .....................489

2. Subsequent Enforcement Actions ..................................491

V. IMPLICATIONS AND RECOMMENDATIONS...................................493

A. Making Administrative Warnings Credible ..........................493

B. Accounting for Publicity Effects ............................................495

C. Implications for Other Administrative Regimes ...................497

VI. CONCLUSION.

\section{INTRODUCTION}

On May 15, 2013, Josh Souza, a Missouri-based commercial dog breeder, received an official warning from the U.S. Department of Agriculture (USDA) for a host of direct and repeat violations of the Animal Welfare Act's (AWA) 
minimum standards. ${ }^{2}$ The warning cautioned, "[a]ny further violation of these federal regulations may result in the assessment of a civil penalty, criminal prosecution, or other sanctions." 3 Six months later, having failed to come into compliance with the law, Souza did not face any of the threatened actions but, instead, received another warning from the agency. ${ }^{4}$ After receiving the second warning, Souza continued to violate welfare standards, including the very same standards for which he had received warnings for violating. Souza's violations included failing to provide shade to dogs who were "panting heavily and had lolling tongues" in 127 degree (F) heat ${ }^{5}$ and failing to provide shelter from wind, rain, and snow while the wind chill was 16.2 degrees $F .{ }^{6}$ A USDA inspector observed a dog shivering and holding up his paws. ${ }^{7}$ Souza was also cited for failing to provide veterinary care to dogs with severely matted fur, which can cause pain, discomfort, and skin sores, and interfere with insulation; ${ }^{8}$ failing to provide veterinary care to an extremely thin dog with protruding shoulder, hip, and spine bones and sunken flanks as well as hair loss, blisters, and nails curling into the pads of his feet; ${ }^{9}$ and holding dogs in an enclosure with feces covering 85\% of the floor. ${ }^{10}$ All told, between February 24, 2014 and July 21, 2016, the USDA inspected Souza thirteen times and cited him for forty-five violations. ${ }^{11}$ Despite this, the agency never proceeded to pursue "a civil penalty, criminal prosecution, or other sanctions" as it had twice warned in 2013. ${ }^{12}$

Is the example of Souza and the USDA aberrant? Is it typical? Administrative agencies frequently use warnings like the ones the USDA issued to Souza-i.e., notifications that the law appears to have been violated and that, if such violations persist, enforcement action may follow-in lieu of more serious enforcement actions. But these warnings present something of a puzzle. As economists Timo Goeschl and Johannes Jarke note, and Souza's case typifies: "[I]t is not at all obvious why it may be in the interest of an enforcer with a compliance objective to respond to a breach of law or regulations with a

${ }^{2}$ Animal \& Plant Health Inspection Serv., U.S. Dep’t of Agric., Official Warning of Josh L. Souza (May 15, 2013).

${ }^{3}$ Id.

${ }^{4}$ Animal \& Plant Health Inspection Serv., U.S. Dep't of Agric., Official Warning of Josh L. Souza (Nov. 5, 2013).

${ }^{5}$ Animal \& Plant Health Inspection Serv., U.S. Dep't of Agric., Inspection Report of Josh L. Souza 1 (July 21, 2016).

${ }^{6}$ Animal \& Plant Health Inspection Serv., U.S. Dep't of Agric., Inspection Report of Josh L. Souza 3 (Feb. 19, 2015).

${ }^{7} I d$. at 4.

${ }^{8}$ Id. at 1 .

${ }^{9}$ Animal \& Plant Health Inspection Serv., U.S. Dep't of Agric., Inspection Report of Josh L. Souza 1 (Feb. 17, 2015).

${ }^{10}$ Animal \& Plant Health Inspection Serv., supra note 6, at 4.

11 Animal \& Plant Health Inspection Serv., U.S. Dep't of Agric., Inspection Reports of Josh L. Souza (Feb. 24, 2014-July 21, 2016).

12 Animal \& Plant Health Inspection Serv., supra note 2; Animal \& Plant Health Inspection Serv., supra note 4. 
warning that imposes no cost on the wrong-doer."13 Despite this puzzle, and despite the prevalence of administrative warnings, virtually no legal scholarship has attended to their efficacy in motivating compliance behavior.

This Article fills that gap in the literature by scrutinizing administrative reliance on warnings both theoretically and in practice, first parsing what economic and other models of enforcement suggest about warnings, and then analyzing the impact of warnings in a particular regulatory context- the Federal Animal Welfare Act. The AWA regulates the treatment of more than 2.5 million animals ${ }^{14}$ at nearly 11,000 locations ${ }^{15}$ across the United States, and is primarily enforced through warnings. ${ }^{16}$

The AWA was selected for analysis for a number of reasons, including the strong public interest in animal welfare, the breadth of the law, the ready availability of considerable records on both inspections and enforcement actions, and the author's expertise in the statute. Notably, these recordsthousands of documents related to AWA enforcement that had been available online for many years-were recently deleted from the USDA's website. ${ }^{17}$ The

${ }^{13}$ Timo Goeschl \& Johannes Jarke, The Warnings Puzzle: An Upstream Explanation, 44 J. REG. ECON. 339, 340 (2013).

${ }^{14}$ Out of more than 2.5 million regulated animals, 820,812 were used for research alone in fiscal year 2016. ANIMAL \& Plant HeAlth INSPECTION SERV., U.S. DEP'T OF AGRIC., ANNUAL REPORT ANIMAL USAGE BY FISCAL YEAR (June 2017), https://www.aphis.usda.gov/ animal_welfare/downloads/reports/Annual-Report-Animal-Usage-by-FY2016.pdf [https://perma. $\mathrm{cc} / 3 \mathrm{BST}-37 \mathrm{C} 4]$.

15 OfFice of Budget \& Program ANAlysis, U.S. DeP'T OF AGRIC., 2018 USDA BUDGET EXPLANATORY NOTES FOR COMMTTTEE ON APPROPRIATIONS: ANIMAL AND PLANT HEALTH INSPECTION SERVICE 20-49, 20-139 (2017) [hereinafter 2018 EXPLANATORY NOTES], https://www.obpa.usda.gov/20aphisexnotes2018.pdf [https://perma.cc/8V97-RPDV].

16 In fiscal year 2017, warnings comprised 157 of 173 AWA enforcement actions taken, or $91 \%$. Animal \& Plant Health Inspection Serv., Animal Care Enforcement Summary $(A W A$ and HPA), U.S. DEP'T OF AGRIC., https//www.aphis.usdagov/aphis/ourfocus/businessservices/ies/ies_performance_metrics/ies-ac_enforcement_summary [https://perma.cc/GNA39WGN] (last modified Nov. 9, 2017); see also OFFICE OF BUDGET \& PROGRAM ANALYSIS, U.S. DEP'T OF AGRIC., 2015 USDA BUDGET EXPLANATORY NOTES FOR COMMITTEE ON APPROPRIATIONS: ANIMAL AND PlaNT HEALTH INSPECTION SERVICE 20-50 (2014) [hereinafter 2015 EXPLANATORY NOTES], http://www.obpa.usdagov/20aphis2015notes.pdf [https://perma.cc/R5HJ-2S7N].

${ }^{17}$ See Animal \& Plant Health Inspection Serv., Animal Welfare Enforcement Actions,
U.S. https://www.aphis.usda.gov/aphis/ourfocus/animalwelfare/enforcementactions [https://perma.cc/ WQT2-RBQA] (last modified Aug. 18, 2017) ("Based on our commitment to being transparent, remaining responsive to our stakeholders' informational needs, and maintaining the privacy rights of individuals, APHIS is implementing actions to remove documents it posts on APHIS' website involving the Horse Protection Act (HPA) and the Animal Welfare Act (AWA) that contain personal information.... These documents include inspection reports, research facility annual reports, regulatory correspondence (such as official warnings), lists of regulated entities, and enforcement records (such as pre-litigation settlement agreements and administrative complaints) that have not received final adjudication."); see also Delcianna J. Winders, Fulfilling the Promise of EFOIA's 
outcry from all corners-not just animal advocates but members of Congress from both sides of the aisle, ${ }^{18}$ industry representatives, ${ }^{19}$ media outlets, ${ }^{20}$ and

Affirmative Disclosure Mandate, 95 DENVER L. REV. (forthcoming 2018), https://ssm.com/abstract=3136093 [https://perma.ce/VX78-QPPV]; Animal \& Plant Health Inspection Serv., Animal Care Information System Website Review Chart, U.S. DEP'T AGRIC., $\quad$ https://www.aphis.usda.gov/aphis/ourfocus/animalwelfare/sa_awa/acis-table [https://perma.cc/XP2F-ESX9] (last modified Aug. 18, 2017) (indicating that enforcement records will not be reposted); Meredith Wadman, USDA Blacks Out Animal Welfare Information, SCIENCE (Feb. 3, 2017), http://www.sciencemag.org/news/2017/02/

trump-administration-blacks-out-animal-welfare-information [https://perma.cc/L6Z2TFL2]. The author is a plaintiff in two lawsuits challenging this blackout. See Complaint for Declaratory \& Injunctive Relief, People for the Ethical Treatment of Animals, Inc. v. Perdue, No. 18-cv-00887 (D.D.C. Apr. 16, 2018); Complaint for Declaratory \& Injunctive Relief, People for the Ethical Treatment of Animals, Inc. v. U.S. Dep't of Agric., 285 F. Supp. 3d 307 (D.D.C. 2018), appeal docketed, No. 18-5074 (D.C. Cir. Mar. 21, 2018); Delcianna J. Winders, Opinion, Why I Sued the USDA, HLL: CONGRESS BLOG (Feb. 16, 2017), http $/ /$ thehill.com/blogs/congress-blog/judicial/319916-why-i-sued-the-usda [https://perma.cc/ AVS4-G4H3].

${ }^{18}$ See Karin Brulliard, Resistance Is Growing to the USDA's Blackout of Animal Welfare Records, WASH. POST: ANIMALIA (Feb. 16, 2017), https:/www.washingtonpost.com/ news/animalia/wp/2017/02/16/resistance-is-growing-to-the-usdas-blackout-of-animal-welfare-reco $\mathrm{rds} /$ ?utm_term=.eb756a4254e7 [https://perma.cc/W697-5NG2] ("[T]his week, 18 Senate Democrats sent a letter to the department's acting deputy, Michael Young, urging a reversal of the decision. A day later, nearly 100 House members sent a similar letter to President Trump asking him to 'immediately restore' the records. Eleven Republicans were among those signing ....").

${ }^{19}$ See, e.g., Nation's Best Zoos and Aquariums Disagree with Decision To Remove Online Access to USDA Inspection Reports, Ass'N ZoOS \& AQUARIUMS (Feb. 6, 2017), https:/www.aza.org/aza-news-releases/posts/nations-best-zoos-and-aquariums-disagree-with-decis ion-to-remove-online-access-to-usda-inspection-re [https://perma.cc/X2WG-ERU7] (reporting the statement of primary U.S. accreditor of zoos and aquariums condemning the blackout) ("Public disclosure of relevant animal care and welfare information represents our license to operate and is essential for ensuring the public's trust and confidence in our profession, enabling the public to distinguish the best animal care facilities from poorly run breeding farms and roadside zoos and menageries ...."); Petland Reacts to USDA Decision, PETLAND (Feb. 6, 2017), http://www.petland.com/news/2017-2-6b.htm [https://perma.co/NN9Q-TWA7] (reporting the statement of large reseller of dogs bred by AWA licensees noting the burdens imposed on it and similarly situated entities by the blackout); The USDA's Removal of Information About Animal Research Is a Step Backwards for Transparency, SPEAKING RESEARCH (Feb. 7, 2017), https://speakingofresearch.com/2017/02/07/the-usdas-removal-ofinformation-about-animal-research-is-a-step-backwards-for-transparency/ [https://perma.cc/VUZ68EER] (raising concerns about the blackout) ("We believe the availability of data can foster an environment of openness and transparency about animal research. When information is hidden, particularly where it was once available, the public will naturally wonder why many stakeholders have cause for concern: the public wonders what is being hidden and why, and researchers must devote even more resources to combatting the public perception that they are not transparent.").

${ }^{20}$ See, e.g., Editorial Board, USDA Puts Blinders on Animal Abuse: Our View, USA TODAY (Feb. 15, 2017), http://www.usatoday.com/story/opinion/2017/02/15/animal-welfarecruelty-website-usda-database-editorials-debates $/ 97950640 /$

[https://perma.cc/2RN9-5E78]; 
others-made clear that animal welfare remains deeply important to the American public. When the AWA was passed in the mid-sixties, Congress received more mail about animal welfare than civil rights and the Vietnam War combined. ${ }^{21}$ The immense attention recently brought to bear on the website blackout $^{22}$ - and near-universal condemnation of the move-underscore that strong public concern about animal welfare persists.

The AWA was passed in 1966 to address "the shocking failure of selfpolicing by the medical community" to ensure the humane treatment of animals used in medical research. ${ }^{23}$ Congress amended the statute in 1970 to extend its protections to animals used for exhibition and the wholesale pet trade, ${ }^{24}$ emphasizing that it was again acting in response to immense public interest. ${ }^{25}$

The stated purpose of the AWA is to ensure the humane care and treatment of animals used for regulated purposes, ${ }^{26}$ and it does so by requiring that those engaged in such purposes become certified with the USDA and submit to unannounced inspections. If the agency determines that violations documented during inspections warrant further action, it uses a variety of approaches, ranging from informal to formal. The "formal" enforcement actions used by the USDA to address AWA violations range from an official warning to a formal administrative complaint seeking relief such as monetary penalties, and license suspension or revocation in an administrative proceeding. Warnings are by far the primary enforcement action used by the agency. ${ }^{27}$

The case study presented in this Article indicates that the USDA's use of warnings as a means of encouraging compliance with the AWA is largely failing - that the example of dog breeder Josh Souza is not aberrant. Facilities

Register's Editorial, Feds Shield Animal Abusers Through Information Blackout, DES MOINES REG. (Feb. 16, 2017), https:/www.desmoinesregister.com/story/opinion/editorials/2017/ 02/16/editorial-feds-shield-animal-abusers-through-information-blackout/97993582/ [https://perma .cc/4PQ3-AUWX].

${ }^{21}$ Forward to ANIMAL Welfare ACT 1966-1996: Historical PerspeCtives AND FUTURE DireCtIONS, at vii, vii (Michael Kreger et al. eds., 1998). Similarly, a 1966 Life Magazine article on conditions at dog-dealer facilities generated more letters to the magazine than any of its stories on Vietnam or civil rights. Christine Stevens, Laboratory Animal Welfare, in ANIMALS AND THEIR LEGAL RIGHTS 66, 74 (4th ed. 1990).

22 See, e.g., supra notes 17-20.

23112 CONG. REC. 13,893 (1966) (statement of Sen. Monroney). (2012).

24 Animal Welfare Act of 1970, Pub. L. No. 91-579, 84 Stat. 1560; 7 U.S.C. $§ 2131(1)$

${ }^{25}$ See Animal Legal Def. Fund, Inc. v. Glickman, 154 F.3d 426, 445 (D.C. Cir. 1998) (en banc) ("The Congressmen who went on the House floor to introduce the act that first extended the AWA to cover animal exhibitions recognized that their bill 'ha[d] been a focal point of concern among animal lovers throughout the Nation for some time'.... Indeed, Congress had placed animal exhibitions within the scope of the AWA after hearings documenting how inhumane conditions at these exhibitions affected the people who came and watched the animals there." (quoting 116 CONG. REC. 40,159 (1970) (statement of Rep. Mizell))).

267 U.S.C. $\S 2131$.

27 See 2015 EXPLANATORY NOTES, supra note 16 , at 20-50 to 20-51. 
that received warnings were more likely to commit six or more subsequent violations than they were to commit zero to one. Nearly $40 \%$ of all facilities that received warnings were subsequently cited for six or more violations of the AWA. And more than one quarter committed one or more direct violationsviolations that have or are likely to have a serious or severe adverse effect on an animal's health and well-being - after receiving a warning.

Given these findings, and suggestions in the literature that credibility is a key element in establishing the effectiveness of a warning, this Article also examines the rate and severity of subsequent enforcement actions for repeat violators of the AWA-i.e., what repercussions those who disregarded agency warnings faced. Again, Souza's example proves unexceptional: repeat warnings were by far the most prevalent subsequent enforcement action. In the rare case where penalties were assessed, they were discounted from the statutory maximum by $96.4 \%$ on average-that is, for every dollar in potential penalties enforceable upon these repeat offenders, they paid just 3.6 cents on average.

This Article reveals a serious enforcement failure. Given the prevalence of warnings as an enforcement tool across administrative agencies, and the paucity of information about their effectiveness, it is likely that similar failures are occurring in a host of other contexts. The Article concludes not with a call to abandon warnings altogether, but with policy recommendations to render them more effective in motivating compliance, with particular attention to the potential role of targeted disclosure, a particularly important issue given the recent trend toward nondisclosure and secrecy where disclosure and transparency were previously the norm.

This Article proceeds as follows: Part II discusses administrative warnings generally. It first establishes the prevalence of warnings as an enforcement tool and then situates warnings within the existing literature, both theoretical and empirical. The Article then aims to tackle two interrelated issues raised in this literature: the puzzle that warnings present to public enforcement theory, and the paucity of empirical analysis of the efficacy of warnings. It does so by analyzing the compliance behavior of facilities regulated under the Federal Animal Welfare Act following the receipt of official warnings. Accordingly, Part III provides background on the AWA - its scope and purposes, how it is implemented, and the various mechanisms utilized to enforce the Act. Part IV then presents a case study of the compliance behavior of regulated facilities following their receipt of warnings for past AWA violations. The analysis also considers the frequency and severity of subsequent enforcement actions faced by the high proportion of facilities that continued to violate the AWA after receiving warnings. Part $\mathrm{V}$ discusses the implications of the case study's findings for both the USDA and administrative agencies more generally, and makes recommendations for policy and further study. 


\section{WARNINGS AND ADMINISTRATIVE ENFORCEMENT}

\section{A. The Prevalence of Administrative Warnings}

As economists Timo Goeschl and Johannes Jarke have noted, "[t]he frequent use of warnings by regulators is an empirical fact in the enforcement of laws and regulations. Research on the activities performed by individual inspectors or by enforcement agencies on a day-to-day basis consistently ranks issuing verbal or written warnings to wrong-doers near the top."28

Warnings are prevalent "across widely different regulatory areas." 29 For example, warnings are frequently used in the context of environmental law. ${ }^{30} \mathrm{~A}$ study of the Environmental Protection Agency's (EPA) enforcement of the Clean Water Act found that $70 \%$ of enforcement actions were informal "nonpunitive actions which involve only a notice or warning that a regulatee is, or may be, in violation of the law."31 A 2012 EPA memo urged staff to consider increasing reliance on notices of violation and warning letters in the early stages of enforcement proceedings 32 "as possible ways of maximizing its enforcement resources." 33

State environmental agencies similarly rely heavily on warnings. "By some estimates, more than $90[\%]$ of state enforcement actions are concluded prior to issuance of administrative penalties or a judicial referral." 34 An analysis of state and local enforcement of air and water quality regulations found that " $[w]$ hen a violation is discovered, by far the most common response is for the agency to

${ }^{28}$ Goeschl \& Jarke, supra note 13, at 33940 (citing Robert A. Kagan, Regulatory Enforcement, in HANDBOOK OF REGULATION AND ADMINISTRATIVE LAW 383, 387 (David H. Rosenbloom \& Richard D. Schwartz eds., 1994)); see also Karine Nyborg \& Kjetil Telle, The Role of Warnings in Regulation: Keeping Control with Less Punishment, 88 J. PUB. ECON. 2801, 2802 (2004) (noting "the popularity of warning policies among regulators").

${ }^{29}$ Goeschl \& Jarke, supra note 13 , at 340.

${ }^{30}$ Heather Eckert, Inspections, Warnings, and Compliance: The Case of Petroleum Storage Regulation, 47 J. ENVTL. ECON. \& MGMT. 232, 232 (2004) ("In Canada and the United States it is common for environmental regulators to respond to a detected violation by issuing a warning rather than prosecuting the violator.").

31 Goeschl \& Jarke, supra note 13, at 349 (citing Susan Hunter \& Richard W. Waterman, Determining an Agency's Regulatory Style: How Does the EPA Water Office Enforce the Law?, 45 W. POL. Q. 403, 409-10 (1992)).

32 Albert Ferlo \& Tom Lindley, Essay, Practical Impacts of the Sackett Decision, 42 ENVTL. L. 1009, 1020 (2012) (citing Memorandum from Pamela J. Mazakas, Acting Dir., Office of Civil Enforcement, Envtl. Prot. Agency, to Regional Enf't Offices \& Personnel 1 (June 19, 2012), https://www.agc.org/sites/default/files/Giles-Memo-RE-CWA-Section309a-ComplOrder-Aft-Sackett.pdf [https://perma.cc/QU5M-NLAY]).

${ }^{33}$ Craig N. Johnston, Essay, Sackett: The Road Forward, 42 ENVTL. L. 993, 1004-05 (2012).

${ }^{34}$ Matthew D. Zinn, Policing Environmental Regulatory Enforcement: Cooperation, Capture, and Citizen Suits, 21 STAN. ENVTL. L.J. 81, 93 (2002); see also id. at 94, tbls.1 \& 2 (showing types of enforcement over years under the Resource Conservation and Recovery Act and the Clean Air Act). 
send the firm a Notice of Violation (NOV), ordering it to return to compliance but taking no further action." 35 A survey of state level enforcement activity found that "most states levied penalties for less than $5[\%]$ of the notices of violation (NOVs) issued each year."36 For example, Oregon's Agricultural Water Quality Management Program relies primarily on "advisories and warnings," only rarely initiating formal enforcement actions. ${ }^{37}$ Thus, $96 \%$ of the program's compliance actions were a warning of some sort, while only $4 \%$ rose to the level of more formal enforcement. ${ }^{38}$

The Food and Drug Administration (FDA) also relies heavily on warnings. According to the FDA's Regulatory Procedures Manual, " $t]$ he Warning Letter is the agency's principal means of notifying regulated industry of violations and achieving prompt voluntary correction." 39 In fiscal year 2015, the FDA issued 17,232 warning letters and sought only twenty-one injunctions. ${ }^{40}$ The number of warnings issued by the FDA also steadily increased, from 673 in fiscal year 2010 , to 4,882 in 2012 , to 6,760 in 2013 , and 17,232 in 2015.41

35 Winston Harrington, Enforcement Leverage when Penalties Are Restricted, $37 \mathrm{~J}$. PUB. ECON. 29, 30 (1988).

${ }^{36}$ Id.

37 Or. DeP'T OF Agric., Oregon Agricultural Water Quality RePOrT 21 (Sept. 2012), https://www.oregon.gov/ODA/shared/Documents/Publications/NaturalResources/ORAgW aterQualityReport.pdf [https://perma.cc/2T3W-DVEN].

${ }^{38}$ Id. at 20 , tbl. 2 (reporting 400 warning-type actions (letter of compliance, advisory action, or letter of warning) and seventeen formal actions (four civil penalties and thirteen notices of noncompliance)).

${ }^{39}$ U.S. FDA, REgUlatory Procedures Manual §4-1-3 (2017), https://www.fda.gov/downloads/ICECI/ComplianceManuals/RegulatoryProceduresManual /UCM074330.pdf [https://perma.cc/BB64-WL5F].

${ }^{40}$ U.S. FDA, FDA ENFORCEMENT STATISTICS SUMMARY: FisCAL YEAR 2015, http://www.fda.gov/downloads/lCECI/EnforcementActions/UCM484400.pdf

[https://perma.cc/3PZP-L4TR]. The vast majority of these warnings were issued by the FDA's Center for Tobacco Products (CTP). See id:; see also Joshua D. Lee, Note, Reconsidering the Traditional Analysis: Should Buckman Alone Support Preemption of Fraud-on-the-FDA Exceptions to Tort Immunity?, 17 N.Y.U. J. LEGIS. \& PUB. POL'Y 1055, 1094 (2014) ("In 2011, the number of warning letters issued nearly tripled from 673 issued in 2010 to 1720 issued in 2011; however, 1040 of those warning letters were issued by the FDA's newly-formed Center for Tobacco Products (CTP) for tobacco products, after Congress gave the FDA authority over tobacco products in 2009. The CTP issued 4146 letters in 2012 and 6052 letters in 2013." (footnotes omitted)). However, warnings are also the predominant enforcement tool used by other FDA programs. See, e.g., James Springer, The Success of the Citizen Suit: Protecting Consumers from Inaccurate Food Labeling by Amending the Federal Food, Drug, and Cosmetic Act, 68 FOOD \& DRUG L.J. 401, 416 (2013) ('[T] he Center for Food Safety and Applied Nutrition ('CFSAN') in fiscal year 2008, issued 134 warning letters for food related violations, yet only sought 3 injunctions and in fiscal year 2011, CFSAN warning letters for food violations increased to 324, yet injunctive enforcement increased to 12." (footnotes omitted)).

41 U.S. FDA, supra note 40; see also Stewart Eisenhart, FDA Data Shows Increase in Warning Letters to Medical Device Firms Since 2005, EMERGo (May 8, 2013), http:/www.emergogroup.com/blog/2013/05/fda-data-shows-increase-warning-letters-medi 
The USDA also uses warnings as a primary enforcement tool. For example, in enforcing the AWA in fiscal year 2017, the agency's Animal Care division issued 157 warnings, entered into fourteen settlement agreements, and filed just two administrative complaints, meaning that warnings comprised more than $90 \%$ of enforcement actions filed. ${ }^{42}$ Animal Care also relied heavily on warnings in enforcing the Horse Protection Act (HPA) in fiscal year 2017: out of 401 enforcement actions, 213 - or $53 \%$-were warnings. ${ }^{43}$ In fiscal year 2016 warnings comprised $98 \%$ of all HPA enforcement actions. ${ }^{44}$ The USDA's Food Safety Inspection Service also issues warnings under the Federal Meat Inspection Act (FMIA) and Poultry Products Inspection Act (PPIA), although information about the number of warnings issued under these statutes does not appear to be readily available. ${ }^{45}$

Other federal agencies that use warnings as an enforcement tool include the National Oceanic and Atmospheric Administration (NOAA), ${ }^{46}$ the Department of Transportation, ${ }^{47}$ and numerous others. ${ }^{48}$

Administrative agencies outside of the United States similarly rely on warnings. For example, as economists Karine Nyborg and Kjetil Telle explain, " $t \mathrm{t}]$ he environmental monitoring and enforcement policy in the [United Kingdom] has also been one of conciliation and repeated warnings, where prosecution has been saved for cases of noncooperativeness and persistent failures to comply." 49 A study of enforcement actions taken against Flemish

cal-device-firms-2005 [https://perma.cc/8FEV-NQ43] (noting steady increase in warning letters issued by FDA specifically to medical device manufacturers); Alexander Gaffney, Enforcement Trends Reveal Record-High Warning Letter Issuances, Common Violations, REG. FoCUS 2 (Aug. 2012), http://www.raps.org/WorkArea/DownloadAsset.aspx?id= 5050 [https:/perma.cc/3N7V-ZNXP] ("Warnings sent to drug manufacturers rose significantly between 2010 and 2010 [sic], with FDA sending 175 Warning Letters in 2011 - the highest number in more than a decade."); Shannon Pettypiece, Drug Advertising Being Toned Down, TELEGRAM.COM (Jan. 31, 2010), http://www.telegram.com/article/20100131/news/1310527 [https://

perma.cc/YX5Y-REHJ ("[T]he agency issued 41 warning letters to drug makers, or almost double the number in 2008.").

42 Animal \& Plant Health Inspection Serv., supra note 16.

43 Id.

44 See id.

${ }^{45}$ See 21 U.S.C. $\$ 676(\mathrm{~b})$ (2012) (authorizing the agency to handle FMIA violations through written warnings); $i d . \S 462$ (same for PPIA).

${ }^{46}$ See 15 C.F.R. $\$ \S 904.400-403$ (2017) (setting forth policies and procedures for issuance and use of written warnings for violations of all statutes administered by NOAA).

${ }^{47}$ See, e.g., 49 C.F.R. $\S \S 107.309$ (2015) (establishing procedures for written warnings for probable pipeline safety violations); id. $\$ 190.205$ (2016) (same).

${ }^{48}$ See, e.g., 15 C.F.R. pt. 766, supp. 1 (2017) (explaining how the Office of Export Enforcement may use warning letters for apparent violations of Export Administration Act); 33 C.F.R. $\S 1.08-5$ (2017) (establishing procedures for issuance of written warnings by Coast Guard boarding officers).

${ }^{49}$ Nyborg \& Telle, supra note 28, at 2802 (citing KEITH HAWKINS, ENVIRONMENT AND ENFORCEMENT 130-31 (1984)); see also RICHARD MACRORY, REGULATION, ENFORCEMENT 
textile companies for violations of environmental regulations found that "in almost ninety percent of the cases where an enforcement action was taken a warning was given to the violator." 50 And under the Norwegian Pollution Control Authority's enforcement policy, "standard procedure is to send a warning letter" when an inspection reveals pollution permit requirement violations. 51

Is such heavy reliance on warnings warranted? The next Subparts begin to explore that question.

\section{B. Theorizing the Role of Warnings}

\section{Warnings Under the Traditional Model of Economic Enforcement}

The traditional economic model used in public enforcement literature posits that entities will only comply with the law "as long as the marginal cost of doing so is less than the expected marginal penalty." 52 Under this model, as economist Heather Eckert succinctly explains, "[a] site will comply if $c<p F$, where $c$ is the site's cost of compliance, $p$ is the detection (inspection) probability, and $F$ is the fine." 53 Accordingly, "increasing the compliance level requires an increase in either the probability of an inspection or the fine." 54

Importantly, "there is no role for warnings in reducing violations" in this model.55 "If a regulator responds to violations with a warning, $F=0$, and any site with positive compliance costs will violate." 56 Put more colloquially, "[i]f potential violators know that they will get a second chance, why should they bother to comply at all before receipt of the warning?"57 Accordingly, as economists Timo Goeschl and Johannes Jarke explain:

[W]arnings have presented something of a puzzle to economists. . . [I]t is not at all obvious why it may be in the interest of an enforcer with a compliance objective to respond to a breach of law or regulations with a warning that imposes no cost on the wrong-doer. ... As a result, the standard economic

AND GOVERNANCE IN ENVIRONMENTAL LAW 30 tbl. 1.1 (2d ed. 2014) (showing prevalence of warnings across a range of U.K. administrative agencies).

${ }^{50}$ Sandra Rousseau, The Use of Warnings in the Presence of Errors, 29 INT'L REV. L. \& ECON. 191, 191 (2009) (citing Sandra Rousseau, Timing of Environmental Inspections: Survival of the Compliant, 32 J. REG. ECON. 17, 26 (2007)).

${ }^{51}$ Nyborg \& Telle, supra note 28, at 2802.

52 Id. at 2801.

${ }^{53}$ Eckert, supra note 30 , at 236.

54 Id.

${ }^{55} \mathrm{Id}$; ; see also id. at $236 \mathrm{n} .9$ ("There are explanations for the existence of warnings in this type of model, but not for their effectiveness at reducing noncompliance.").

56 Id. at 236.

${ }^{57}$ Nyborg \& Telle, supra note 28 , at 2802; see also Harrington, supra note 35 , at 31 ("[]] $\mathrm{f}$ enforcement activity is carried on at such a low level, and if violations are rarely punished even if discovered, why would any firm bother to comply?"). 
model of public enforcement has remained largely silent on the issue of warnings. 58

On this view, it would appear irrational for regulatory agencies to issue warnings in lieu of penalties, and we should expect warnings to have no effect on compliance behavior. However, as discussed in the next Subpart, some scholars have urged a move away from a strict economic model to account for other factors that may inform regulated entities' compliance behavior. These models, in turn, may provide a meaningful place for warnings.

\section{Socio-Legal Studies, Responsive Regulation, and the Turn Away from a Strict Economic Model}

For years, a debate has raged between scholars advocating for a coercive regulatory approach and those urging a more cooperative approach. ${ }^{59}$ The coercive approach is premised on the economic model discussed above, which holds that "regulated entities are rational economic actors whose principal motivations include maximization of profits." 60 Proponents of a more cooperative approach, sometimes referred to as "compliance assistance," contend that regulated entities are not solely motivated by a fear of detection and punishment and that there is great value in establishing and maintaining a cooperative relationship between regulator and regulatee. According to this view, an overly "sanction-oriented' response to noncompliance may make regulated entities 'resentful' and less likely to cooperate with regulators in the future."61

${ }^{58}$ Goeschl \& Jarke, supra note 13, at 340; see id. at 350 ("[Widespread use of warnings has] been identified as an anomaly within the standard theory of public law enforcement: As a first-order approximation, a breach of regulations should always attract punishment by an enforcer with a compliance objective, unless the enforcer decides not to pursue the offender at all. The use of warnings, which are costly to the enforcer and costless to the offender, is therefore puzzling."); see also Eckert, supra note 30, at 232 ("[T] he traditional framework does not provide an active role for warnings ....").

59 See, e.g., Michael Faure, Effectiveness of Environmental Law: What Does the Evidence Tell Us?, 36 WM. \& MARY ENVTL. L. \& POL'Y REV. 293, 327 (2012) (“A lot of theoretical literature has dealt with the question of whether authorities should be hard on polluters and should prosecute all cases, often referred to as the deterrence model, or whether negotiations between the polluter and the enforcer, whereby the agency tries to bring the polluter to compliance through persuasion and by providing information, referred to as the cooperation model, can be more effective."); Thomas O. McGarity, When Strong Enforcement Works Better than Weak Regulation: The EPA/DOJ New Source Review Enforcement Initiative, 72 MD. L. REV. 1204, 1274-89 (2013) (discussing the debate and the arguments on both sides).

${ }^{60}$ Robert L. Glicksman \& Dietrich H. Earnhart, Depiction of the Regulator-Regulated Entity Relationship in the Chemical Industry: Deterrence-Based Vs. Cooperative Enforcement, 31 WM. \& MARY ENVTL. L. \& POL'Y REV. 603, 612 (2007).

$61 \mathrm{Id}$. at 617 (citing CLIFFORD RECHTSCHAFFEN \& DAVID L. MARKELL, REINVENTING ENVIRONMENTAL ENFORCEMENT \& THE STATE/FEDERAL RELATIONSHIP 68 (2003)). 
Although this debate continues to some extent, as Sidney A. Shapiro and Randy S. Rabinowitz have noted:

Most analysts are convinced that both cooperation and punishment are necessary to optimize enforcement efforts. For these analysts, the crucial question is "not which enforcement strategy regulators should usecooperative or punitive-but when." Thus, regulators must "distinguish between 'bad' and 'good' firms... and employ the tools of punitive and cooperative enforcement ...., thereby maximizing the virtue of each approach while minimizing their vices." 62

As socio-legal scholar Robert A. Kagan and his colleagues have explained, research has found that concerns about detection and legal punishment are not the sole factors motivating businesses, but are intertwined with other motivational factors, principally "concern about the consequences of acquiring a bad reputation; and a sense of duty, that is, the desire to conform to internalized norms or beliefs about right and wrong." 63 In their view, the traditional, rationalactor economic model oversimplifies the motivations of regulated entities and ignores part of the picture. ${ }^{64}$

62 Sidney A. Shapiro \& Randy S. Rabinowitz, Punishment Versus Cooperation in Regulatory Enforcement: A Case Study of OSHA, 49 ADMIN. L. REV. 713, 724 (1997) (alteration in original) (footnote omitted) (quoting JOSEPH V. REES, REFORMING THE WORKPLACE 176 (1988)).

${ }^{63}$ Robert A. Kagan et al., Fear, Duty, and Regulatory Compliance: Lessons from Three Research Projects, in EXPLAINING COMPLIANCE 37, 37 (Christine Parker \& Vibeke Lehmann Nielsen eds., 2011); see also Glicksman \& Earnhart, supra note 60, at 623-24 ("The cooperative approach to enforcement proceeds on the premise that regulated entities react to a variety of motives that include not only maximizing the bottom line, but also 'internaliz[ing] the general societal norms about environmental protection,' taking advantage of good compliance records to enable a firm to market itself as green, and creating an image of environmental responsibility that may attract investment." (footnote omitted) (quoting RECHTSCHAFFEN \& MARKELL, supra note 61, at 215)).

64 The framework offered by Kagan et al. is not without its critics. While beyond the scope of this Article, it is worth noting that some have raised concerns about the publicity effects operating as sanctions without due process. See, e.g., Third Amended Complaint at 43, Contender Farms, L.L.P. v. U.S. Dep't of Agric., No. 4:16-cv-01630-O (N.D. Tex. Oct. 3,2016 ). However, even the fiercest critics of "agency threats" have acknowledged that they are generally not judicially reviewable. See, e.g., Ethan W. Blevins, Life in the Law's Shadow: Due Process in the World of Rule by Threat, 27 GEO. MASON U. C.R.L.J. 1, 28 (2016) ("A threat, though often speaking in certain terms, will usually be considered a tentative or interlocutory action-one that begins the enforcement process but has no legal consequences in itself. Thus, the threat itself does not trigger judicial review under the APA."); see also Rhea Lana, Inc. v. Dep't of Labor, 824 F.3d 1023, 1028 (D.C. Cir. 2016) ("Agencies routinely use such letters to warn regulated entities of potential violations before saddling them with expensive and demanding enforcement actions. Treating such reminders of regulated parties' legal obligations as final and judicially reviewable agency action would discourage their use, 'quickly muzzl[ing] . . informal communications between agencies and their regulated communities...that are vital to the smooth operation of both government and business." (quoting Indep. Equip. Dealers Ass'n v. Envtl. Prot. Agency, 
The reputational concerns that Kagan et al. suggest we attend to are comprised of pressures for responsible performance "from neighbours, employees, community groups, the news media and environmental advocacy groups," all of which "could generate adverse publicity." 65 These pressures are intertwined with and largely based on a foundation of government regulation and enforcement, which provide "benchmarks for criticizing firms that appear to have violated them." 66 "Moreover, by publicizing a violation, social license enforcers amplify an official legal sanction's impact and deterrent weight. Adverse publicity concerning regulatory violations can erode the 'reputational capital' that most firms work hard to build and protect." 67

Normative concerns, in turn, are described as "[c]ivic duty motivations, including the felt obligation to comply with [the] law" separate from fear of punishment. ${ }^{68}$ Like reputational concerns, normative motivations also largely derive their governing standards and expectations from legal rules and a prospect of enforcement. 69

If the compliance behavior of regulated entities is motivated by a complex mix of factors, not simply fear of detection and punishment, then regulators seeking to incentivize compliance should attend to that mix of factors. As Ayres and Braithwaite have suggested, "Government should ... be attuned to the differing motivations of regulated actors" and "should respond to industry conduct."70 Their approach, which they call "responsive regulation," calls for a context-specific view of "what triggers regulatory intervention" as well as "what

372 F.3d 420, 428 (D.C. Cir. 2004))); Nat'l Ass'n of Home Builders v. U.S. Envtl. Prot. Agency, 956 F. Supp. 2d 198, 212 (D.D.C. 2013) ("[A]gency actions that merely warn regulated entities are not considered to be [judicially reviewable] final agency actions, as they do not 'determin[e] rights or obligations' nor do 'legal consequences flow' from them." (citing Holistic Candlers \& Consumers Ass'n v. FDA, 664 F.3d 940, $944-45$ (D.C. Cir. 2012))), aff'd sub nom. Nat'l Ass'n of Home Builders v. Envtl. Prot. Agency, 786 F.3d 34 (D.C. Cir. 2015).

${ }^{65}$ Kagan et al., supra note 63, at 42.

${ }^{66} \mathrm{Id}$.

${ }^{67}$ Id.; see also Sally S. Simpson et al., An Empirical Assessment of Corporate Environmental Crime-Control Strategies, 103 J. CRIM. L. \& CRIMINOLOGY 231, 239 (2013) ("When reputational damages stem mainly from formal legal proceedings, this can be seen as part of a deterrence strategy. However, informal sanctions also impose stigmatic, commitment, and attachment costs for managers who violate the law. These effects may be a direct consequence of formal sanctions or completely unrelated to formal proceedings.... [A] study of corporate offending intentions... found inhibitory effects associated with the certainty of internally imposed informal sanctions (shame) and externally imposed informal sanctions (loss of respect from family, friends, and business associates). Importantly, the threat of both individual and firm reputational damage had an inhibitory effect. But these effects were independent of and tended to trump formal sanction risks (which were relatively unimportant sources of deterrence)." (footnotes omitted)).

${ }^{68}$ Kagan et al., supra note 63 , at $44-45$.

${ }^{69}$ Id. at 41.

${ }^{70}$ IAN Ayres \& JoHn BRAITHWAIte, RESPONSIVE REgulation 4 (1992). 
the response should be."71 Responsive regulation "proposes a principled way in which to combine the insights from plural theories of compliance and enforcement, including those that propose people comply only when they calculate it is in their self-interest to do so, and those that see people complying for normative or social reasons." 72 Responsive regulation "has been explicitly adopted by a wide range of regulators."73

Responsive regulation, Ayres and Braithwaite have suggested, can be accomplished through an enforcement pyramid. As depicted below:

Most regulatory action occurs at the base of the pyramid where attempts are initially made to coax compliance by persuasion. The next phase of enforcement escalation is a warning letter; if this fails to secure compliance, imposition of civil monetary penalties; if this fails, criminal prosecution; if this fails, plant shutdown or temporary suspension of a license to operate; if this fails, permanent revocation of license. ${ }^{74}$

${ }^{71} \mathrm{Id}$.

72 Vibeke Lehmann Nielsen \& Christine Parker, Testing Responsive Regulation in Regulatory Enforcement, 3 REG. \& GoVERNANCE 376, 376 (2009) (citations omitted).

${ }^{73} \mathrm{Id}$. at $376-77$.

${ }^{74}$ A YRES \& BRAITHWAITE, supra note 70, at 35-36. License revocation is at the top of the pyramid, as it incapacitates through "corporate capital punishment." Id. at 53. 
Figure 1: Ayres and Braithwaite's Enforcement Pyramid

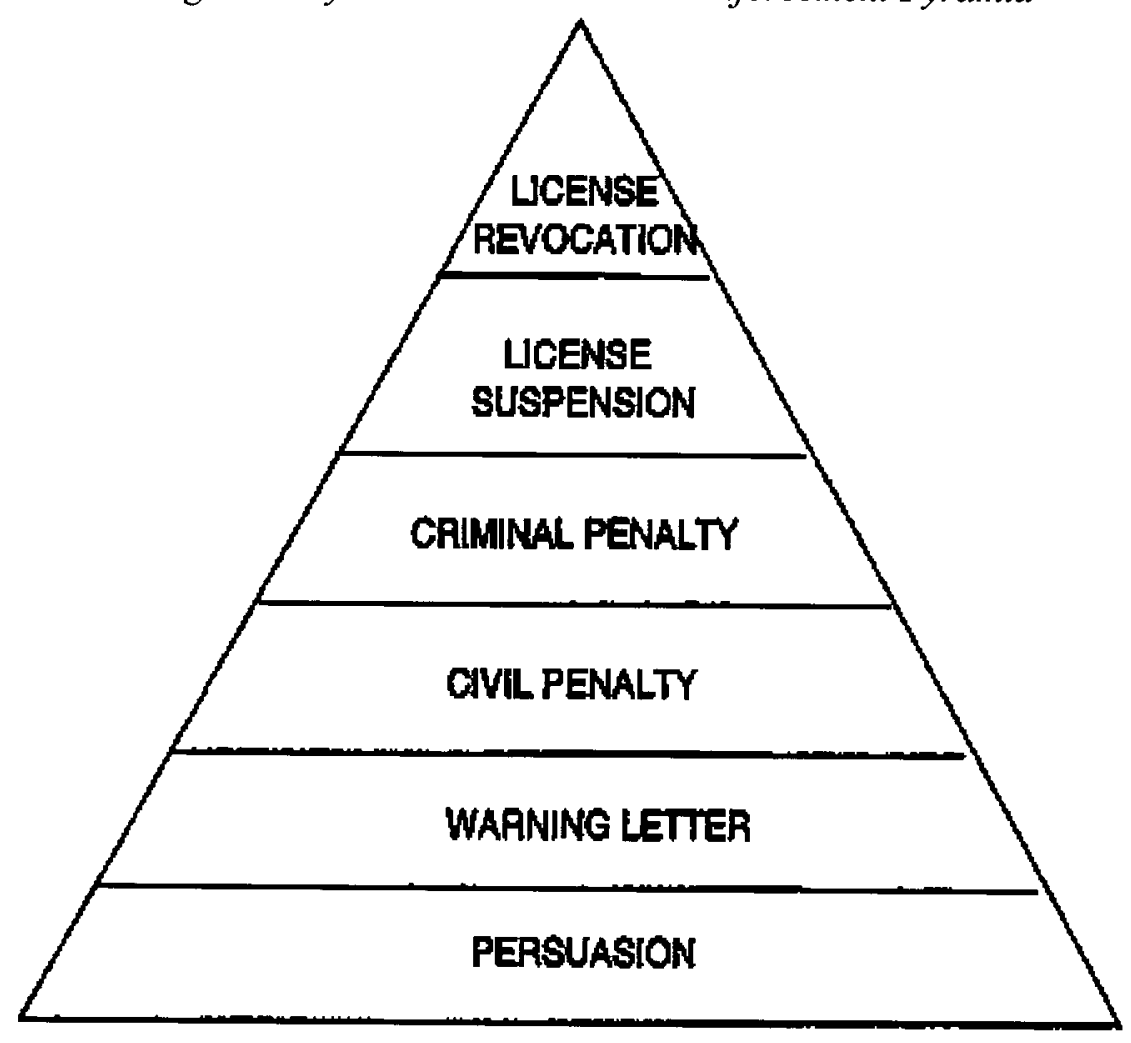

With an enforcement pyramid, the vast majority of regulatory interactions are cooperative, but this cooperation relies fundamentally on the ability of the State to escalate enforcement - " $[1]$ op the tops off the enforcement pyramids and there is less prospect of self-regulation, less prospect of persuasion as an alternative to punishment." 75 Under this model, "the greater the heights of punitiveness to which an agency can escalate, the greater its capacity to push regulation down to the cooperative base of the pyramid."76 Also important is the ability to provide gradual escalation. As Ayres and Braithwaite explain, when agencies have only extremely punitive enforcement options-such as completely shutting down a business- - it is politically impossible and morally unacceptable to use it with any but the most extraordinary offences. Hence, such agencies often find themselves in the situation where their implied plea to "cooperate or else' has little credibility." 77 Thus, "compliance is most likely

${ }^{75}$ Id. at $38-39$.

${ }^{76} \mathrm{Id}$. at 40.

${ }^{77}$ Id. at 36; see also Todd Lochner \& Bruce E. Cain, Equity and Efficacy in the Enforcement of Campaign Finance Laws, 77 TEX. L. REV. 1891, 1901-02 (1999) ("[T]he ability ... to impose--or threaten to impose-a variety of enforcement sanctions . . ensur[es] that the [regulatory] agency is not forced to choose between low-cost, low-impact remediation and high-cost, high-impact criminal sanctions."). 
when regulators (1) have access to an armory of deterrent and incapacitative weapons, and (2) when they avoid both the mistake of selecting a sledge hammer to swat a fly and selecting a flyswatter to stop a charging bull."78

This approach-which scholars have deemed "the most sustained and influential account of how and why to combine deterrent and cooperative regulatory enforcement strategies"79_also allows for the possibility that not all violations of the law are deliberate. As Todd Lochner and Bruce E. Cain note, the pyramid "approach is often appropriate because it recognizes an obvious reality of most regulatory environments"- that "many regulatees violate the law by accident or misunderstanding rather than by design." ${ }^{80}$ Kagan et al. similarly note that regulatory enforcement officials have found that most violations "stem from inattention or miscalculation of risks by particular company subunits or employees, or by unexpected technical or business pressures that induce harried subunit managers or employees to postpone or modify time-consuming regulatory compliance routines." 81 In such scenarios, warnings might be sufficient to bring companies back into compliance. Relatedly, Murat C. Mungan has suggested that warnings may be optimal and socially desirable where individuals are uninformed about the illegality of the act at issue as they "are meant to give notice to or caution individuals who are presumed to lack information regarding a certain issue." 82 Used in this way, warnings can incentivize compliance at a low cost while also preserving a sense of cooperation between the government and the regulated entity, who may perceive enforcement where they are uninformed to be unfair, thereby "weakening the social ties between citizens and law enforcers." 83

Returning to Kagan et al.'s framework of the three principal factors motivating compliance by regulated entities, the issuance of a warning can have significant reputational and normative implications. If warnings are made public, they can generate the adverse publicity that firms try hard to avoid. This concern alone might motivate a regulated entity to avoid a warning even if it carries no true legal penalty. Likewise, if, as Kagan et al. suggest, firms have

${ }^{78}$ AYRES \& BRAITHWAITE, supra note 70 , at 52.

${ }^{79}$ Nielsen \& Parker, supra note 72, at 377.

${ }^{80}$ Lochner \& Cain, supra note 77, at 1903-04; see also Faure, supra note 59, at 328 ("Criminological research in the Netherlands has shown that many violations of environmental regulation do not take place willfully, but rather as a result of a lack of information or knowledge. In these cases where companies lack adequate information, a deterrence approach may fail and a cooperative enforcement style could be more effective. This was also confirmed in a recent experimental study by Alpizar and others who showed that there are substantial learning effects, meaning that compliance with the desired pollution reduction targets is substantially higher in a second period when the firm was accurately informed about the contents of their obligations." (footnote omitted)).

81 Kagan et al., supra note 63 , at 47.

82 Murat C. Mungan, Optimal Warning Strategies: Punishment Ought Not To Be Inflicted Where the Penal Provision Is Not Properly Conveyed, 9 REV. L. \& ECON. 303, 305 n.6 (2013) (citing Warning, BLACK's LAW DICTIONARY 1615 (8th ed. 2004)).

83 Id. at 306. 
normative motivations separate from a fear of penalties, a warning may suffice to motivate compliance.

Thus, the enforcement pyramid approach allows for the existence of both "good apples" and "bad apples," balancing cooperation and coercion. As Shapiro and Rabinowitz explain, while

regulators should cooperate with firms that attempt in good faith to comply with agency regulations, they must also aggressively punish lawbreakers that do not act in good faith. Such enforcement is necessary to deter firms that do not intend to comply and to ensure continued compliance by those firms that voluntarily comply. In other words, there is an enforcement paradox. An agency will not be able to engage in effective cooperation unless it is committed to aggressive pursuit of serious lawbreakers . . .84

Punishment, then, plays a crucial role; without it the system collapses. Warnings are effective because they convey a credible threat of future enforcement in the face of continued noncompliance. ${ }^{85}$ Indeed, one empirical study found that "credible legal sanctions" are one of the single "most effective regulatory levers." 86 As the Supreme Court noted in distinguishing the mere availability of civil penalties and the actual imposition thereof in Friends of the Earth, Inc. v. Laidlaw Environmental Services (TOC), Inc., "a threat has no deterrent value unless it is credible that it will be carried out."87

Without credibility, warnings are essentially meaningless. ${ }^{88}$ Shapiro and Rabinowitz explain:

84 Shapiro \& Rabinowitz, supra note 62 , at 729.

85 See John T. Scholz, Managing Regulatory Enforcement in the United States, in HANDBOOK OF REGULATION AND ADMINISTRATIVE LAW, supra note 28, at 423,426 ("Flexibility in enforcement can potentially compensate for the inherent inefficiency of uniform regulations when applied to heterogeneous settings. However, flexibility can only develop after a credible deterrence threat has been established."); see also MACRORY, supra note 49, at 29 ("[A]dvice and incentives should play a key role in ensuring regulatory compliance, and should normally be the first response of regulators. Nevertheless, an effective sanction regime plays an equally vital role in a successful regulatory regime. It underpins the regulator's advisory functions, and its very existence will often act as an inducement to compliance without the need to invoke the formal sanctions."); William L. Andreen, Motivating Enforcement: Institutional Culture and the Clean Water Act, 24 PACE ENVTL. L. REV. 67, 67 (2007) ("Vigorous enforcement is a critical component of any credible environmental protection program."); George Gilligan et al., Civil Penalties and the Enforcement of Directors' Duties, 22 U. NEW S. WALES L.J. 417, 426 (1999) ("[T]he regulator must accept the reality of non-compliance and be prepared to move 'up' the enforcement pyramid.").

${ }^{86}$ Simpson et al., supra note 67, at 232.

${ }^{87}$ Friends of the Earth, Inc. v. Laidlaw Envtl. Servs. (TOC), Inc., 528 U.S. 167, 186 (2000).

${ }^{88}$ Zinn, supra note 34 , at 89 ("The firm may be deterred from remaining noncomplian[t] by the risk that the agency will eventually impose penalties, but that deterrent effect must be minimal where the agency consistently follows a cooperative strategy."). 
[I]f a regulated entity lacks sufficient incentives to comply voluntarily with agency regulations, a cooperative enforcement approach is not likely to induce compliance. To the contrary, the agency's failure to punish the firm results in its continued noncompliance. Unless the firm's incentives are shifted by the imposition of penalties, its managers have no reason to change their behavior. ${ }^{89}$

Further, "the failure to punish violators can lead to less voluntary compliance" by the "good apples": "If regulatory agencies fail to detect and punish violators, other firms will decline to comply because cooperation will put them at a competitive disadvantage with the noncompliers. ${ }^{\prime 90}$ In other words, enforcement serves, in part, "as a defense of the legitimacy of the governmental intervention that sustains voluntary compliance." 91

Thus, follow-up on administrative warnings is essential to their effectiveness. ${ }^{92}$ In short, "[u]nless regulated entities comply with the obligations imposed on them by the ... laws, or are forced to answer for noncompliance,

${ }^{89}$ Shapiro \& Rabinowitz, supra note 62 , at 723-24; see also MACRORY, supra note 49, at 71 ("Failure to follow up notices to check that compliance has been reached can undermine ... [warnings] as a sanctioning tool, and could encourage reluctant businesses not to take them seriously."); Lochner \& Cain, supra note 77, at 1901 (“[T] he regulator ... must develop a reputation for imposing prompt and costly legal sanctions if the regulated entity fails to keep its bargains."); Scholz, supra note 85, at 442 ("Persuasion begins with a solid enforcement program. As many enforcement officials have observed, a strong voluntary compliance program has to hit hard at the bad apples to keep them from spoiling the good ones who 'comply voluntarily.' ... The persuasive strategy requires the agency to use maximal enforcement with firms that have established a record of poor compliance in the past ...."); Michelle Welsh, Civil Penalties and Responsive Regulation: The Gap Between Theory and Practice, 33 MELB. U. L. REV. 908, 914 (2009) ("If resort to the persuasive measures located at the base of the pyramid does not achieve the desired result, the regulator must be prepared to advance to a higher level in the pyramid.").

${ }^{90}$ Shapiro \& Rabinowitz, supra note 62 , at 724 ("In her examination of tax enforcement, for example, Margaret Levi stresses that active prosecution of violators is crucial because perceptions of 'exploitation' will encourage noncompliance." (citing MARGARET LEVI, OF RULE AND REVENUE 53 (Brian Berry et al. eds., 1988))); see also Kagan et al., supra note 63, at 52 (noting that one important function of enforcement is "its reassurance effect ('you're not a fool to comply; we are really looking for and finding the bad apples')"); McGarity, supra note 59, at 1278 ("Strict deterrence-based enforcement levels the playing field for maximal compliers who err on the side of compliance with the environmental laws. To the extent that they get away with conduct that violates the law, flouters and minimal compliers obtain a competitive advantage over maximal compliers that can be reflected in the prices of their competing products." (footnote omitted)); Scholz, supra note 85 , at 443 ("The more mistakes the agency makes in ... failing to prosecute bad [firms], the less the incentive to cooperate.").

91 JOEL A. MinTZ, ENFORCEMENT AT THE EPA 2 (rev. ed. 2012).

92 See MACRORY, supra note 49, at 44 ("[F]ollow up ... is of particular importance for low-level enforcement actions such as warning letters or enforcement/improvement notices, where I am concerned that lack of follow-up on the part of regulators means that they are not taken seriously and credibly by firms."). 
those laws will represent an impressive-looking edifice that in reality is little more than an empty lot fronted by a flimsy facade. ${ }^{.93}$

\section{Paucity of Empirical Data on the Efficacy of Warnings}

Despite a robust literature on the relative theoretical merits of coercive and cooperative regulatory enforcement approaches, there is surprisingly little data on the actual efficacy of either approach. As Robert L. Glicksman and Dietrich H. Earnhart have noted:

For all the debate that the recent emphasis on cooperative approaches to assuring compliance with the environmental laws has engendered, relatively little empirical research has been directed at a comparison of the traditional, deterrence-based (or coercive) enforcement approach and the cooperative enforcement approach to inducing compliance with environmental regulatory obligations. 94

Numerous other scholars have similarly noted the paucity of empirical data in this area. ${ }^{95}$

The efficacy of warnings specifically is even more severely understudied. Despite their prevalence, we know remarkably little about whether warnings actually work to incentivize compliance. As Nyborg and Telle have remarked, "There is a considerable literature on enforcement of regulations, but we know of no analysis explicitly analyzing the role of warnings... . The role of warnings ... seems largely ignored in the economics literature . . . .966 Given the dearth of such analysis, Eckert notes that "little is understood about the role

93 Glicksman \& Earnhart, supra note 60 , at 605 .

$94 \mathrm{Id}$. at 608.

95 See, e.g., Victor B. Flatt \& Paul M. Collins, Jr., Environmental Enforcement in Dire Straits: There Is No Protection for Nothing and No Data for Free, 85 NOTRE DAME L. REV. 55,62 (2009) ("Despite the major shift in theories regarding enforcement in the last two decades, empirical analyses and testing of these strategies have been limited."); Nielsen \& Parker, supra note 72, at 377 ("Researchers have rarely sought to set out general, empirically testable rules about being a 'responsive' regulator."); Scholz, supra note 85, at 426-27 ("Although studies of police behavior have conceptualized a range of alternative enforcement techniques and compiled systematic empirical evidence about differential effectiveness, regulatory enforcement studies have focused primarily on the very basic deterrence question of whether enforcement activities in general (primarily inspections, citations, and penalties) are related to increased compliance and the accomplishment of policy goals, theory development has been left at a level of generality that is of little direct relevance to the choices made by enforcement officials." (citations omitted)); Shapiro \& Rabinowitz, supra note 62, at 720 ("There is little empirical evidence on the relative effectiveness of cooperative and legalistic enforcement policies. Most of the evidence is anecdotal and open to dispute." (footnote omitted)).

96 Nyborg \& Telle, supra note 28, at 2803; see also Rousseau, supra note 50, at 191 ("Informal enforcement instruments, such as warnings and advices, are only rarely studied. Warnings are, nonetheless, often used as an enforcement instrument ...."). 
and effectiveness of warnings as an enforcement tool. 997 As a result, agencies' heavy reliance on warnings "has been more of an act of faith than a rational policy choice. $" 98$

The limited research on cooperative approaches generally suggests caution. Shapiro and Rabinowitz note that " $[t]$ he policy evidence is equivocal concerning the extent to which such agency cooperation increases regulatory compliance. Other evidence, however, suggests that substantial reliance on cooperation may decrease compliance." 99 Specifically, they suggest that "[a] mix of anecdotal and empirical evidence warns that cooperative approaches can decrease compliance if agencies permit law breakers to go unpunished." 100 They cite a Canadian study that "found that the same employers continued to violate health and safety regulations despite lenient treatment,"101 and an empirical study which compared compliance in the pulp and paper industries in Canada and the United States found lower compliance rates in Canada, which the author attributed to the fact that Canadian enforcers were more lenient than their American counterparts when addressing noncompliance. ${ }^{102}$ Notably, in both of these studies it appears that the enforcement bodies were not escalating penalties in the face of ongoing noncompliance, making it unsurprising that the noncompliance persisted and suggesting a need for close examination of effects of meaningful escalation and credible threats on compliance behavior.

With this background in mind, this Article aims to contribute to the virtual void in scholarship on the efficacy of warnings. Given the pervasive use of warnings as an enforcement tool-indeed, often as the primary enforcement tool- by administrative agencies today, the lack of information about their effectiveness is astonishing. More information is urgently needed if our regulatory approaches are to be effective and efficient. Toward that end, this Article analyzes the use and efficacy of warnings in the context of the most

${ }^{97}$ Eckert, supra note 30, at 234.

98 Glicksman \& Earnhart, supra note 60 , at 608 n.24.

${ }^{99}$ Shapiro \& Rabinowitz, supra note 62, at 716.

$100 \mathrm{Id}$. at 722.

${ }^{101}$ Id. (citing Richard Brown, Theory and Practice of Regulatory Enforcement: Occupational Health and Safety Regulation in British Columbia, 16 LAW \& POL'Y 63, 8384 (1994)). This study found that "fewer than one-fifth of employers with poor compliance records, averaging five or more repeat orders per inspection, were punished," causing the author to conclude "that the limited use of penalties is the result of institutionalized tolerance of widespread violations, rather than the result of the vast majority of firms being good apples." Id. at 723 n.40 (citing Brown, supra, at 83-84).

102 Id. at 722-23 ("Another empirical study which compared compliance in the pulp and paper industries in Canada and the United States found lower compliance rates in Canada, which the author attributed to the fact that Canadian enforcers were more lenient than their American counterparts when addressing noncompliance. An Australian analyst came to a similar conclusion based on his observations of efforts to enforce mine safety and health in Australia." (footnote omitted) (first citing Kathryn Harrison, Is Cooperation the Answer? Canadian Environmental Enforcement in Comparative Context, 14 J. POL'Y ANALYSIS \& MGMT. 221, 240 (1995); and then citing NELL GUNNINGHAM, SAFEGUARDING THE WORKER $272(1984)))$. 
comprehensive federal law governing the treatment of animals, the Animal Welfare Act.

\section{ThE ANIMAL WELFARE ACT}

\section{A. The AWA's Purposes and Scope}

The Animal Welfare Act ${ }^{103}$ is the most comprehensive U.S. law governing the treatment of animals. Under the Act, Animal Care, a subdivision of the U.S. Department of Agriculture's Animal and Plant Health Inspection Service (APHIS), regulates the treatment of more than 2.5 million animals ${ }^{104}$ held at nearly 11,000 sites. ${ }^{105}$

The Act has three stated purposes:

(1) to insure that animals intended for use in research facilities or for exhibition purposes or for use as pets are provided humane care and treatment;

(2) to assure the humane treatment of animals during transportation in commerce; and

(3) to protect the owners of animals from the theft of their animals by preventing the sale or use of animals which have been stolen. ${ }^{106}$

Originally enacted as the Laboratory Animal Welfare Act in 1966, the Act initially focused on the supply and treatment of dogs, cats, nonhuman primates, guinea pigs, hamsters, and rabbits used for research. ${ }^{107}$ Congress subsequently expanded the scope of the Act to cover additional commercial activities and categories of animals. Today, the AWA regulates warm-blooded animals-with some significant exceptions - when they are used for research, exhibition, or the wholesale pet trade, and when they are transported in connection with these activities. 108

Certain activities that would otherwise fall within the law's scope are exempted, as are certain categories of animals. One significant exemption is the

1037 U.S.C. $\$ \S 2131-2159$ (2012).

104 See supra note 14.

105 See supra note 17.

1067 U.S.C. $\$ 2131$.

107 Pub. L. No. 89-544, 80 Stat. 350 (1966).

1087 U.S.C. $\$ 2131$. Notably not covered by the AWA are animals raised for food. See id.; see also id $\S 2132(\mathrm{~g})$ ("The term 'animal' ... excludes ... farm animals, such as, but not limited to livestock or poultry, used or intended for use as food or fiber, or livestock or poultry used or intended for use for improving animal nutrition, breeding, management, or production efficiency, or for improving the quality of food or fiber."). The fact that these animals are not covered by the AWA - or any other federal statute during the bulk of their lives - has been the subject of criticism. See, e.g., David J. Wolfson \& Mariann Sullivan, Foxes in the Hen House: Animals, Agribusiness, and the Law: A Modern American Fable, in ANIMAL Rights 205, 207-08 (Cass R. Sunstein \& Martha C. Nussbaum eds., 2004). 
exclusion of rats, mice, and birds when they are bred for research, ${ }^{109}$ even though (or, perhaps more likely, precisely because) these animals comprise the vast majority of warm-blooded animals used for research. ${ }^{10}$ In addition, while the USDA acknowledges that birds are intended to be covered by the Act when used for regulated purposes, except when they are bred for research, ${ }^{11}$ the agency has never actually regulated birds. ${ }^{112}$ Other exemptions exclude horses except when used for research purposes; ${ }^{113}$ "[s]tate and count $\rceil y$ fairs, livestock shows, rodeos, purebred dog and cat shows, and any other fairs or exhibitions intended to advance agricultural arts and sciences"; 114 and animal dealers and exhibitors whose business size has been deemed de minimis. ${ }^{115}$

\section{B. AWA Standards, Certification, and Inspections}

The Animal Welfare Act requires compliance with minimum animal welfare standards. Entities engaged in activities covered by the AWA are required to become certified by the USDA and to submit to unannounced inspections intended to assess for compliance with these standards.

\section{Animal Welfare Standards}

\section{The AWA directs the USDA to promulgate "minimum requirements:"}

for handling, housing, feeding, watering, sanitation, ventilation, shelter from extremes of weather and temperatures, adequate veterinary care, and separation

1097 U.S.C. $\$ 2132$ (g) ("The term 'animal' .. excludes ... birds, rats of the genus Rattus, and mice of the genus Mus, bred for use in research ...."). Congress enacted this exception in 2002, Farm Security and Rural Investment Act of 2002, Pub. L. No. 107-171, $\S 10301,116$ Stat. 134,491 , following years of litigation and a settlement agreement in which the USDA had agreed to regulate rats, mice, and birds. See Stipulation of Dismissal at 1, Alts. Research \& Dev. Found. v. Glickman, 101 F. Supp. $2 d 7$ (D.D.C. 2000) (No. Civ.A. 99-581).

$11097 \%$ of research in the United Kingdom and $93 \%$ in the European Union is performed on mice, rats, birds, and fish, species which are not regulated in the United States under the AWA. USDA Publishes 2016 Animal Research Statistics - 7\% Rise in Animal Use, SPEAKING RESEARCH, https://speakingofresearch.com/2017/06/19/usda-publishes-2016-animal-researchstatistics-7-rise-in-animal-use/ [https:/perma.ce/S997-KW9D].

${ }^{111}$ See Animal Welfare; Definition of Animal, 69 Fed. Reg. 31,513 (June 4, 2004).

${ }^{112}$ See People for the Ethical Treatment of Animals v. U.S. Dep't of Agric., 797 F.3d 1087, 1091-95 (D.C. Cir. 2015); Complaint for Declaratory \& Injunctive Relief, Am. AntiVivisection Soc'y v. U.S. Dep't of Agric., No. 2:18-cv-01753-PD (E.D. Pa. Apr. 26, 2018).

1137 U.S.C. $\$ 2132(\mathrm{~g})$.

${ }^{114} \mathrm{Id}$. $\S 2132(\mathrm{~h})$. Although not mentioned in the statute, the USDA has also exempted dog races by regulation. 9 C.F.R. $\S 1.1$ (2017).

1157 U.S.C. $\$ 2133$; see also id. $\$ 2132$ (h) ("The term 'exhibitor' . . excludes . . a an owner of a common, domesticated household pet who derives less than a substantial portion of income from a nonprimary source (as determined by the Secretary) for exhibiting an animal that exclusively resides at the residence of the pet owner ...."). 
by species where the Secretary finds necessary for humane handling, care, or treatment of animals; ... for exercise of dogs, as determined by an attending veterinarian in accordance with general standards promulgated by the Secretary,... for a physical environment adequate to promote the psychological well-being of primates, 116

and for "the handling, care, and treatment" of animals being transported in commerce. ${ }^{117}$ These regulatory standards are set forth at 9 C.F.R. $\$ \S 3.1-$ 3.142. ${ }^{118}$ The vast majority of animals are governed by what are referred to as "generic" standards, ${ }^{119}$ while cats, dogs, guinea pigs, hamsters, marine mammals, primates, and rabbits are each governed by somewhat more specific standards. ${ }^{120}$

The Act also calls for additional regulatory requirements for animals used for research, including requirements intended to ensure that "alternatives to any procedure likely to produce pain to or distress in an experimental animal" are considered; to limit the use of animals in "more than one major operative experiment"; and, in the case of procedures "likely to produce pain to or distress in an experimental animal," to govern veterinary consultation, "the use of tranquilizers, analgesics, and anesthetics," "pre-surgical and post-surgical care," "the use of paralytics without anesthesia," and the "withholding of tranquilizers, anesthesia, analgesia, or euthanasia."121 Relatedly, the Act requires each research facility to form a committee, usually referred to as an institutional animal care and use committee, that is responsible for conducting inspections to ensure compliance with these research requirements. ${ }^{122}$ The regulatory standards governing these research requirements and the committees tasked with overseeing them are set forth at 9 C.F.R. $\S 2.31$.

The USDA stresses that the standards under the Act are the bare minimum and "encourage[s]" regulated entities "to exceed these standards."'123

\section{Certification Under the AWA}

The Animal Welfare Act's primary mechanisms are a licensing/registration (collectively, "certification") and inspection regime. Anyone who wants to deal

$116 / d . \S 2143(\mathrm{a})(2)$.

117 Id. $\S 2143(\mathrm{a})(4)$.

$118 \mathrm{~A}$ few of the statutorily required minimum standards also appear in 9 C.F.R. part 2. See, e.g., 9 C.F.R. $\$ 2.40$ (setting forth minimum standards for veterinary care).

119 See id. $\$ \S 3.125-3.142$ (setting forth "Specifications for the Humane Handling, Care, Treatment, and Transportation of Warmblooded Animals Other than Dogs, Cats, Rabbits, Hamsters, Guinea Pigs, Nonhuman Primates, and Marine Mammals").

120 See id. $\S \S 3.1-3.118$.

1217 U.S.C. $\$ 2143(\mathrm{a})(3)$.

122 Id. $\$ 2143(\mathrm{~b})$.

123 ANIMAl \& Plant Health InSPECTIOn SERv., U.S. DeP'T OF AGRIC., ANIMAL Care FACTSHEET: THE ANIMAL WELFARE ACT (2012); see also JAMES F. GESUALDI, EXCELLENCE BEYOND COMPLIANCE (2014). 
in or exhibit regulated animals must obtain a license, ${ }^{124}$ while anyone who wants to engage in animal research, as well as commercial carriers that transport animals, must register their business with the USDA. ${ }^{125}$

Under the AWA, applicants for an initial license must be inspected by the agency and, during that inspection, must demonstrate compliance with the minimum regulatory standards discussed above. ${ }^{126}$ Licenses expire after one year, and currently the agency does not inspect prior to renewal or withhold renewal based on violations of the standards, a practice that has faced considerable criticism, including from the USDA's own Office of Inspector General (OIG). ${ }^{127}$ Registered facilities must renew their registration every three years. ${ }^{128}$ The agency currently does not inspect facilities before registering them, even for the first time, ${ }^{129}$ a practice that the OIG has also criticized. ${ }^{130}$

\section{U.S.C. $\$ 2133$. An animal dealer is defined as}

any person who, in commerce, for compensation or profit, delivers for transportation, or transports, except as a carrier, buys, or sells, or negotiates the purchase or sale of, (1) any dog or other animal whether alive or dead for research, teaching, exhibition, or use as a pet, or (2) any dog for hunting, security, or breeding purposes.

Id. $\S 2132(\mathrm{f})$.

125 Id. $\S 2136$. The differential treatment of research facilities is rooted in concerns about interference with scientific research. "Carrier" is defined as "the operator of any airline, railroad, motor carrier, shipping line, or other enterprise, which is engaged in the business of transporting any animals for hire." Id. $\S 2132(\mathrm{j})$.

${ }^{126}$ Id. $\S 2133 ; 9$ C.F.R. $\S \S 2.1-2.11$ (2017). License applicants are given three opportunities to demonstrate compliance, after which they must wait six months before reapplying. $I d$. $\S 2.3(\mathrm{~b})$.

${ }_{27}$ See generally Delcianna J. Winders, Administrative License Renewal and Due Process-A Case Study, FLA. ST. U. L. REV. (forthcoming 2018-2019), https $/ /$ ssrn.com/abstract=2952062 [https://perma.cc/DL94-8VN5] (describing criticisms and urging that the agency condition renewal on compliance); see also OFFICE OF INSPECTOR GEN., U.S. DEP'T OF AGRIC., AUdIT REPORT No. 33002-0001-CH, ANIMAL AND Plant HeAlth InsPection SERVICE - IMPLEMENTATION OF THE ANimal Welfare ACt 11 (Mar. 1992) [hereinafter 1992 OIG AUDIT REPORT] (stating that USDA's failure to "require that facilities be in compliance with the act to obtain license renewals" results in "reduced assurance that animal care facilities will make required corrections to comply with the provisions of the act to ensure the humane care and treatment of animals"); id. at 14 ("APHIS should ensure that dealer facilities are in compliance with the intent of the Animal Welfare Act through the use of compliance inspections prior to the renewal of licenses.").

1289 C.F.R. $\$ 2.25(\mathrm{a})$.

129 See id. (requiring only completing and filing a form to register).

130 OFFICE OF INSPECTOR GEN., U.S. DEP'T OF AGRIC., AUDIT REPORT NO. 33600-1-CH, ANIMAL AND PLANT INSPECTION SERVICE ENFORCEMENT OF THE ANIMAL WELFARE ACT 15 (Jan. 1995) [hereinafter 1995 OIG AUDIT REPORT] ("Although not specifically required by the regulations, pre-registration inspections are the only reliable means at APHIS' disposal to ensure that the facilities which it registers are operating in compliance with the provisions of the Act. Because a newly registered facility may not be inspected for up to a year, the Department could be subject to adverse publicity if serious violations by such a facility become public knowledge."). The OIG has urged USDA to "[r]equire that inspections be 
The USDA provides initial license applicants and registrants with a copy of the AWA regulations and standards, and requires that they "acknowledge receipt of" and "agree to comply with" the regulations and standards by signing a form. ${ }^{131}$ License renewal applicants are also required to certify compliance but are provided with another copy of the standards and regulations only on request. ${ }^{132}$

Once licensed or registered, regulated facilities are subject to unannounced inspections to assess for compliance with the standards. ${ }^{133}$

\section{AWA Inspections}

Animal Care employs approximately 100 inspectors ${ }^{134}$ to inspect more than 2.5 million animals ${ }^{135}$ at nearly 11,000 regulated sites. ${ }^{136}$ The AWA mandates that research facilities be inspected at least annually, ${ }^{137}$ but sets no inspection frequency for other types of regulated facilities. The agency uses what is referred to in the literature as regulator "targeting"138 and what it calls a "risk-

performed at all animal research and handling facilities prior to registration, and that registrations be withheld from any facility which is not in compliance." Id.

1319 C.F.R. § 2.2(a) (licensing); id. $\$ 2.26$ (registration).

${ }^{132}$ Id. $\$ 2.2(\mathrm{~b})$.

1337 U.S.C. $\$ 2146$ (a) (2012) ("The Secretary shall make such investigations or inspections as he deems necessary to determine whether any dealer, exhibitor, intermediate handler, carrier, research facility, or operator of an auction sale subject to section 2142 of this title, has violated or is violating any provision of this chapter or any regulation or standard issued thereunder, and for such purposes, the Secretary shall, at all reasonable times, have access to the places of business and the facilities, animals, and those records required to be kept pursuant to section 2140 of this title of any such dealer, exhibitor, intermediate handler, carrier, research facility, or operator of an auction sale."). These inspections are unannounced. See Animal \& Plant Health Inspection Serv., Animal Welfare Act Inspections, U.S. DEP'T AGRIC., https:/www.aphis.usda.gov/aphis/ourfocus/animalwelfare/sa_awa/ct_awa inspections [https://perma.cc/V4QK-VX3K] (last modified Nov. 13, 2017); OFFICE OF INSPECTOR GEN., U.S. DEP'T OF AGRIC., AUDIT REPORT NO. 33601-0001-41, ANIMAL AND Plant Health InSPECtion SERVICE OVERSight of RESEARCH FaCILITIES 1 (Dec. 2014) [hereinafter 2014 OIG AUDIT REPORT], https:/www.usda.gov/oig/webdocs/33601-0001-41.pdf [https//perma.cc/Q6E7-7PWP]; ANIMAL \& PLANT HEALTH INSPECTION SERV., U.S. DEP'T OF AGRIC., ANIMAL CARE FACTSHEET: COMPLIANCE INSPECTIONS 1 (2012) [hereinafter FACTSHEET: COMPLIANCE INSPECTIONS], https:/www.aphis.usda.gov/publications/animal welfare/content/printable_version/fs_compliance_inspection.pdf [https://perma.cc/W9YC-9EUG].

${ }^{134}$ E-mail from Kay Carter-Corker, Assistant Deputy Adm'r, Animal Care, Animal \& Plant Health Inspection Serv., U.S. Dep't of Agric., to Howard Baskin, Advisory Bd. Chairman, Big Cat Rescue (Oct. 31, 2016, 4:19 PM) (on file with Ohio State Law Journal) (104 total inspectors); see also 2014 OIG AUDIT REPORT, supra note 133, at 5 (125 inspectors in fiscal year 2010).

1352018 EXPLANATORY NOTES, supra note 15, at 20-139.

136 Id. at 20-49.

1377 U.S.C. $\$ 2146(a)$.

138 See Faure, supra note 59, at 329-30 (discussing targeting and its effectiveness). 
based inspection system" to determine inspection frequencies. ${ }^{139}$ Under this system, facilities that are "consistently in compliance" are inspected less frequently-once every two to three years-while "problem facilities" are inspected more frequently - as often as every three months. ${ }^{140}$ In addition, if an inspection reveals violations ${ }^{141}$ "that have, or are likely to have, a serious impact on the well-being of the animals," inspectors are required to reinspect within forty-five days. ${ }^{142}$ These reinspections typically focus only on the prior citation(s) impacting animal welfare and are accordingly referred to as "focused" inspections. ${ }^{143}$ The USDA also accepts complaints from the public and will inspect "in response to legitimate concerns and complaints."144

An inspection report is generated for every AWA inspection ${ }^{145}$ and, until recently, after a twenty-one-day appeal window, ${ }^{146}$ was made available online with minimal redactions in a public, searchable database, where it remained for a three-year period. ${ }^{147}$ The inspection report contains a summary of any

${ }^{139}$ See Animal \& Plant Health Inspection Serv., supra note 133; see also Animal \& Plant Health Inspection Serv., Risk Based Inspection System, U.S. DEP'T AGRIC., https:/www.aphis.usda.gov/aphis/ourfocus/animalwelfare/sa_awa/ct_awa_risk_based_inspection_ system [https://perma.cc/9FQB-835A] (last modified Aug. 15, 2016).

${ }_{140}$ Animal \& Plant Health Inspection Serv., supra note 139; see also 2015 EXPLANATORY NOTES, supra note 16, at 20-50 (calling for facilities that have been flagged as high-risk that are cited for repeat violations to be reinspected within ninety days).

141 "APHIS synonymously used the terms violations, alleged violations, and noncompliant items in its documents." OFFICE OF INSPECTOR GEN., U.S. DEP'T OF AGRIC., AUDIT REPORT NO. 33002-4-SF, ANIMAL AND PLANT HEALTH INSPECTION SERVICE ANIMAL CARE Program InSPECTIONS OF ProblematiC DEALERS 1 n.5 (May 2010) [hereinafter 2010 OIG AUDIT REPORT], https://www.usdagov/oig/webdocs/33002-4-SF.pdf[https://perma.cc/B3P3 -AM68].

142 Animal \& Plant Health Inspection Serv., supra note 139. However, according to the most recent available data from the agency, only $61 \%$ of repeat violators are reinspected within the prescribed time frame. Response to APHIS FOIA Request No. 11-152 (Mar. 8, 2011) (on file with Ohio State Law Journal).

143 See U.S. DEP'T OF AGRIC., ANIMAL WELFARE INSPECTION GUIDE 3-22 (2013) [hereinafter ANIMAL WELFARE INSPECTION GUIDE], https://www.aphis.usdagov/animal_welfa re/downloads/Animal-Care-Inspection-Guide.pdf [https:/perma.cc/CYH6-4ZPJ].

${ }_{144}$ Animal \& Plant Health Inspection Serv., supra note 133.

145 See, e.g., FACTSHEET: COMPLIANCE INSPECTIONS, supra note 133 ("Once the inspection is completed, the inspector documents any noncompliant items or issues that require correction in an inspection report and takes photographs as needed.").

146 ANImAl \& Plant Health InSPECtion SERV., U.S. DeP'T OF Agric., ANimal Care TECH NOTE: INSPECTION REPORT APPEALS PROCESS 1--2 (June 2017), https://www.aphis.usda. gov/publications/animal_welfare/2017/AC-Tech-Note-Inspection-Report-Appeals-Process.pdf [https://perma.cc/DQ46-5L24].

${ }^{147}$ See supra notes 17-20 and accompanying text. Even before the website blackout, under a recently implemented policy referred to as "Teachable Moments," not all noncompliant items were included on inspection reports. See E-mail Bulletin from U.S. Dep't of Agric., USDA Animal Care Revises Its Animal Welfare Inspection Guide (Jan. 14, 2016), https://content.govdelivery.com/accounts/USDAAPHIS/bulletins/13044a6 [https://permacc/ADX6-32AP]. Noncompliant items that meet certain criteria were instead 
noncompliant items, also referred to by the agency as violations or citations, including the number of animals impacted, sorted by the regulatory provision at issue. ${ }^{148}$ A correction deadline is also generally included for each item on the report. 149

The inspection report is also supposed to specifically note any "direct," "critical," or "repeat" violations. 150 "Direct" noncompliant items are those that "at the time of the inspection" are "having a serious or severe adverse effect on the health and well-being of the animal, or ha[ve] the high potential to have that effect in the immediate future."151 For example, as explained in the AWA

deemed "teachable moments" and noted on a separate "Teachable Moments worksheet" that is not part of the inspection report and not readily available to the public. Id. "A teachable moment is a minor non-compliant item that: 1) the facility is willing and able to correct quickly; 2) is not impacting the welfare of any animal(s); and 3) has not previously been cited." Id. This policy was reportedly announced at a meeting with dog breeders, by USDA officials who explained that the USDA needs "to enable breeders to sell their dogs to pet stores" and suggested that violations are "an impediment to such sales." PA Dog Law Board Member Hired by USDA, UNITED AgAINST PUPPY Mills (Oct. 4, 2016), https:/unitedagainstpuppymills.org/2016/10/04/pa-dog-law-board-member-hired-usda/ [https://per ma.cc/V2C2-JXG6]. The USDA Office of Inspector General has noted that Teachable Moments are being "used inconsistently" and not properly documented. OFFICE OF INSPECTOR GEN., U.S. DEP'T OF AGRIC., AUDIT REPORT NO. 33601-0001-31, APHIS: ANIMAL WELFARE ACT - MARINE MAMMALS (CETACEANS) 10-12 (May 2017) [hereinafter 2017 OIG AUDIT REPORT], https:/www.usda.gov/oig/webdocs/

33601-0001-31.pdf [https://perma.cc/Q6E7-7PWP].

148 ANIMAL WELFARE INSPECTION GUIDE, supra note 143, at 2-7 to 2-8.

149 Id.; see also ANIMAL. \& Plant HeAlth InSPECTION SERV., U.S. DEP'T OF AGRIC., ANIMAL CARE FACTSHEET: ANIMAL EXHIBITORS 2 (2012), https://www.aphis.usda.gov/publications/animal_welfare/content/printable_version/fs_anexhit. pdf [https://perma.cc/ECB4-N4S5] ("If an inspection reveals deficiencies in complying with the AWA standards and regulations, the APHIS official documents the deficiencies and gives the facility a timeframe for correction. This timeframe is determined by the severity of the infraction and the direct risks to the animals' health and well-being."); FACTSHEET: COMPLIANCE INSPECTIONS, supra note 133 ("For each issue that requires correction, the specific applicable regulation is cited, along with a description of the problem and a deadline by which the issue must be corrected."). As noted above, reinspections are required within forty-five days for serious violations. See supra note 142 and accompanying text. For other violations, despite the assignment of a correction date, reinspection is not required. In addition, for repeat violations that previously received a correct-by date yet persist, a new correct-by date is not assigned.

150 ANIMAL WELFARE INSPECTION GUIDE, supra note 143, at 2-7 to 2-8; see also id. at 2-9 to 2-10 (noting critical noncompliant items are violations that resulted in serious or severe adverse effect on an animal, but occurred in the past and also include falsification of records, refusal to permit inspection, and interfering with, harassing, or threatening an APHIS official). A 2010 audit by the USDA Office of Inspector General found that nearly one in three inspectors failed to "correctly report all repeat or direct violations." 2010 OIG AUDIT REPORT, supra note 141, at 2; see also id. at 21-23 (providing examples). The audit also found that "inspectors did not always document violations with sufficient evidence." Id. at 17.

151 ANIMAL WELFARE INSPECTION GUIDE, supra note 143, at 2-10. 
inspection guide used by inspectors, a heavy flea or tick infestation would be a "direct" violation, as would use of tranquilizers on an animal to facilitate public handling. ${ }^{152}$ "Critical" violations include direct violations as well as "prior adverse event[s] that had serious or severe animal welfare consequences to one or more animals, but pose[] no current risks to the animals," and, inter alia, chronic unavailability for inspections, falsification of records, and interfering with, harassing, or threatening an APHIS official. ${ }^{153}$ Repeat noncompliances are two sequential violations of the same regulatory subsection. ${ }^{154}$ They need not involve the same animal(s) to qualify as repeats.

Notably, a recent USDA Office of Inspector General audit found that AWA "inspections are not always performed consistently" and that, as a result, "APHIS may not be able to provide assurance that those exhibitors subject to inspection are in compliance with all requirements of AWA."155

\section{AWA Enforcement}

\section{Statutory Provisions Pertaining to Enforcement}

The penalties available under the AWA depend on the type of facility at issue. For violations by a research facility, the AWA allows for civil monetary penalties of up to $\$ 11,390$ per violation, as well as cease-and-desist orders. ${ }^{156}$ All other regulated entities are subject to these penalties in addition to license suspension or revocation. ${ }^{157}$ For any statutory penalty, with the exception of a temporary license suspension of twenty-one days or fewer, the AWA provides

152 Id. at B-2; see also id. at B-2 to B-5 (providing additional examples as guidance for inspectors).

153 Id. at 2-9 to $2-10$.

${ }^{154}$ Id. at 2-8. "The 'Repeat' designation may be also be used if the section and subsection have been cited as a Repeat citation multiple times within the last 3 years, even if it was not cited on the last full inspection." Id.; see also 2010 OIG AUDIT REPORT, supra note 141, at 9 ("AC narrowly defines a repeat violator as one that consecutively violates the same subsection of the animal welfare regulations. This means that on successive inspections a dealer can violate different sections of the regulations without being labeled a repeat violator and, therefore, the inspector is not required to recommend an enforcement action.").

1552017 OIG AUDIT REPORT, supra note 147, at 9-10.

1567 U.S.C. $\$ 2149$ (b) (2012); 7 C.F.R. § 3.91(b)(2)(ii) (2017) (adjusting for inflation); Civil Monetary Penalty Inflation Adjustment for 2018, 83 Fed. Reg. 11,129, 11,132 (Mar. 14,2018 ) (to be codified at 7 C.F.R. pt. 3). Failure to comply with a cease and desist order is subject to a penalty of $\$ 1708$, id., "for each offense, and each day during which such failure continues shall be deemed a separate offense," 7 C.F.R. $\S 3.91$ (b)(2)(ii). As is standard, civil penalty monies go to the general Treasury, not to the agency. See Nyborg \& Telle, supra note 28 , at 2809 ("To our knowledge, it is uncommon that regulatory agencies can add collected penalties to their own budgets ....").

1577 U.S.C. $\$ 2149$ (a). As noted above, research facilities are treated differently out of concerns with interfering with research. See supra note 125 and the accompanying text. 
for a right to a notice and hearing. ${ }^{158}$ Although not required by law, ${ }^{159}$ the USDA currently provides for a full, on-the-record hearing in all cases, ${ }^{160}$ a practice that the agency's Office of Inspector General has criticized as causing undue delays. ${ }^{161}$

The AWA gives the USDA the authority to "compromise" any civil penalty162 and instructs the agency to "give due consideration to the appropriateness of the penalty with respect to the size of the business of the person involved, the gravity of the violation, the person's good faith, ${ }^{163}$ and the history of previous violations" when calculating monetary penalties. 164

Criminal penalties are also available under the AWA for dealers, exhibitors, and auction operators, ${ }^{165}$ but are exceedingly rare in practice. ${ }^{166}$ In addition, the Act requires the USDA to refer matters to the Attorney General for injunctive relief where animal welfare violations are "placing the health of any animal in

1587 U.S.C. $\$ 2149$ (a) (requiring notice and hearing for longer license suspension or revocation); id. $\S 2149$ (b) ("No penalty shall be assessed or cease and desist order issued unless such person is given notice and opportunity for a hearing with respect to the alleged violation, and the order of the Secretary assessing a penalty and making a cease and desist order shall be final and conclusive unless the affected person files an appeal from the Secretary's order with the appropriate United States Court of Appeals.").

${ }^{159}$ See generally Winders, supra note 127, at 9-13 (reviewing hearing requirements under the Administrative Procedure Act).

${ }^{160}$ See 9 C.F.R. $\S 4.1$ (2017) (stating that the Department Rules of Practice apply to all AWA proceedings); 7 C.F.R. $\S \S 1.130-1.151$ (setting forth those rules).

161 The OIG has noted that the use of "court hearings to apply civil penalties" results "in an excessive period of time to assess civil penalties." 1992 OIG AUDIT REPORT, supra note 127, at 11, 13.; see also id. at 15 (finding that reliance on Administrative Law Judge system results in excessive time to remove problematic facilities from the program). In 1992, the OIG suggested: "APHIS should implement procedures which would allow for hearing cases outside the Administrative Law Judge system. Therefore, APHIS should request from the Secretary of Agriculture a waiver from the requirements of the Department Rules of Practice for facilities continuously violating the Animal Welfare Act." Id. at 15. For further discussion of these issues, see Winders, supra note 127 , at $40-41$.

1627 U.S.C. $\$ 2149$ (b).

163 "Good faith includes a person who has animals that are in good health and do not suffer as a result of the violations, and cooperates with IES and AC." 2014 OIG AUDIT REPORT, supra note 133 , at 17 n.38.

1647 U.S.C. $\$ 2149$ (b).

$165 I d . \S 2149(\mathrm{~d})$.

166 There were five criminal AWA cases in 2017; all of them focused on animal fighting rather than the regulatory provisions discussed in this article. Animal Welfare, U.S. DEP'T JUSTICE, https://www.justice.gov/enrd/animal-welfare [https://perma.cc/9NWZ-AA48]. 
serious danger" or where an entity "is dealing in stolen animals,"167 but it appears that this provision has never been utilized. ${ }^{168}$

\section{AWA Enforcement Practices}

When Animal Care determines that noncompliant items documented during an inspection warrant further action, it has a number of options, including issuing a warning, entering into a settlement agreement, or seeking formal enforcement by initiating a hearing.

\section{a. Warnings}

For less serious violations, Animal Care may issue a letter of warning. ${ }^{169}$ According to USDA enforcement policies, a warning may be issued if an entity is still out of compliance after a ninety-day reinspection, has accrued multiple repeat citations, is making slow progress toward compliance, or has been cited for a direct violation that has "no obvious effects on animal health or

1677 U.S.C. $\$ 2159$ (a) ("Whenever the Secretary has reason to believe that any dealer, carrier, exhibitor, or intermediate handler is dealing in stolen animals, or is placing the health of any animal in serious danger in violation of this chapter or the regulations or standards promulgated thereunder, the Secretary shall notify the Attorney General, who may apply to the United States district court in which such dealer, carrier, exhibitor, or intermediate handler resides or conducts business for a temporary restraining order or injunction to prevent any such person from operating in violation of this chapter or the regulations and standards prescribed under this chapter.").

${ }^{168} \mathrm{~A}$ response to a Freedom of Information Act (FOIA) request submitted to the Department of Justice (DOJ) for such referrals yielded a response that "no records responsive to your request were located." Letter from Vanessa R. Brinkmann, Senior Counsel, Office of Info. Policy, U.S. Dep't of Justice, to author (Nov. 17, 2016) [hereinafter Letter from Vanessa R. Brinkman to author] (on file with Ohio State Law Journal). The author is still awaiting a response to a similar request submitted to the USDA on July 8, 2016.

1692015 EXPLANATORY NOTES, supra note 16, at 20-50; see also OFFICE OF INSPECTOR GEN., U.S. DEP'T OF AGRIC., AUdit REPORT No. 33002-3-SF, APHIS ANIMAL CARE PROGRAM INSPECTION AND ENFORCEMENT ACTIVITIES 2 (Sept. 2005) [hereinafter 2005 OIG AUDIT REPORT]. In addition to warning letters, the agency also uses an even more lighthanded alternative, a "Letter of Information." See 2010 OIG AUDIT REPORT, supra note 141, at $5 \& \mathrm{n} .12$ (describing a "letter of information" as "an informal warning letter" and noting that "[i]n 2007, AC discontinued 'letter of information' as an enforcement option"). Although the agency has indicated that letters of information were discontinued, this appears to be false, as an FOIA request for such letters submitted by the author to the USDA yielded more than 200 pages of such letters that were sent between 2013 and 2016. See Response to APHIS FOIA Request No. 15-05453 (on file with Ohio State Law Journal) (containing letters of information sent by Animal Care); see also Response to APHIS FOIA Request Regarding Teachable Moments, at 71 (on file with Ohio State Law Journal) (containing materials related to the development and dissemination of Teachable Moments guidance) (noting, as part of a Q\&A document, that "[o]ther actions the Agency may take in lieu of fines/suspensions/revocations include the issuance of letters of information and/or Formal Warning Notices"). 
welfare." 170 USDA policy also dictates that "an official warning can be sent if no other enforcement action"-including a warning- "was taken against the violator in the previous 3 years."171 As the example of the dog breeder Souza discussed in the introduction to this Article evinces, and as further discussed below, the agency does not appear to adhere to this policy strictly, if at all. ${ }^{172}$

The USDA considers warnings to be an "immediate deterrent,"173 and states that issuance of a warning "allows APHIS to address infractions in a timely manner, and facilities to improve their overall compliance before further action is necessary." 174 These assertions by the agency are interrogated later in this Article. ${ }^{175}$

Warnings are typically sent to the regulated entity by certified mail. The warning, also referred to as a 7060, for the agency form number, is labeled "OFFICIAL WARNING VIOLATION OF FEDERAL REGULATIONS," and states, "The U.S. Department of Agriculture has evidence that on or about [specified date(s)], you or your organization committed violations of the following sections of the Code of Federal Regulations, Title 9."176 The warning then provides a brief description of the violation(s), including the date(s), and regulatory provision(s) violated. ${ }^{177}$ Sometimes no specific facts about the

170 Animal \& Plant Health InSPECTION SERV.: ANimal CARE, U.S. DeP'T OF AGRIC., $\begin{array}{llll}\text { CHECKLIST FOR ANIMAL CARE INSPECTION REPORT 12, } & \text {, }\end{array}$ https:/www.aphis.usda.gov/animal_welfare/downloads/Inspection_Requirements_Attachments.P DF [https://perma.cc/86UT-NUKB].

${ }^{171} 2010$ OIG AUDIT REPORT, supra note 141, at 13 (citing to “Animal Care Enforcement Action Guidance for Inspection Reports distributed to [Animal Care] staff in 2007”); see also ANIMAL \& Plant HEALTH INSPECTION SERV.: ANIMAL CARE, supra note 170, at 12 (stating that a warning is only appropriate where there have been no enforcement actions other than a ninety-day re-inspection in the preceding three years). Repeated attempts to clarify with the agency whether this policy is in effect, given the failure to adhere to it, went unanswered. See E-mails from Delcianna J. Winders, Academic Fellow, Animal Law \& Policy Program, Harvard Law School, to Sarah Conant, Dir. of Enf't, Animal \& Plant Health Inspection Serv. (Apr. 19, 2016, Apr. 25, 2016, May 3, 2016, May 10, 2016) (on file with Ohio State Law Journal). An FOIA request pertaining to this matter also failed to illuminate the issue. Request from Delcianna Winders, FOIA Request No. 2016-APHIS-02112-F (Feb. 4, 2016) (requesting "[a] copy of the Animal Care Enforcement Action Guidance for Inspection Reports ... as well as any similar subsequent guidance documents that may have been issued").

172 See infra Part IV.

1732015 EXPLANATORY NOTES, supra note 16, at 20-50; see also Andrew D. Cardon et al., Understanding USDA's Enforcement Process, 42 LAB ANIMAL 13, 13 (2013) ("[A]n Official Warning Letter . . may be issued with or without an investigation by IES.").

1742015 EXPLANATORY NOTES, supra note 16 , at 20-108.

175 See infra Parts IV-V.

176 See, e.g., Animal \& Plant Health Inspection Serv., supra note 2 (official warning from USDA-APHIS to Josh L. Souza); Animal \& Plant Health Inspection Serv., supra note 4 (official warning from USDA-APHIS to Josh L. Souza).

${ }^{177}$ See, e.g., Animal \& Plant Health Inspection Serv., supra note 2 (official warning from USDA-APHIS to Josh L. Souza); Animal \& Plant Health Inspection Serv., supra note 4 (official warning from USDA-APHIS to Josh L. Souza). 
particular violation(s) are provided, but a brief description can typically be found by cross-referencing the inspection report(s) for the date(s) referenced on the warning. Toward the bottom of the form, in small font, it states "Any further violation of these federal regulations may result in the assessment of a civil penalty, criminal prosecution, or other sanctions."178

The USDA sends a cover letter with a warning that includes the statement, "This notice is being issued at this time as a serious warning that if you fail to comply with the requirements of the AWA in the future, this citation and all past and future documented violations will be used to justify a more severe penalty." 179 The letter notes the maximum monetary penalty per violation. ${ }^{180}$ AWA warnings do not require a response, and their prior issuance is not held against a licensee in any subsequent enforcement actions. ${ }^{181}$

Violations that the USDA deems too serious to qualify for a warning are referred to APHIS's Investigative and Enforcement Service (IES). ${ }^{182}$ After conducting an investigation, if IES decides to pursue enforcement, it may ultimately decide to issue an official warning, offer the violator a settlement agreement, or refer the case to the USDA Office of General Counsel (OGC) to be considered for more formal action. ${ }^{183}$ The USDA acknowledges that fines are "very rare."184

\section{b. Settlement Agreements}

Settlement agreements typically focus on monetary penalties, and "APHIS typically offers to settle for a civil penalty that is much lower than the maximum civil penalty authorized in the relevant statute."185 The USDA's Office of

${ }^{178}$ See, e.g., Animal \& Plant Health Inspection Serv., supra note 2 (official warning from USDA-APHIS to Josh L. Souza); Animal \& Plant Health Inspection Serv., supra note 4 (official warning from USDA APHIS to Josh L. Souza).

${ }^{179}$ See, e.g., Letter from Gerald Rushin, Assistant Deputy Adm'r, Animal Care, Animal \& Plant Health Inspection Serv., to Living Treasures II, Inc. (Mar. 17, 2016) (on file with Ohio State Law Journal).

180 As of 2011 , however, the agency was citing the wrong amount, failing to account for a 2008 statutory increase in the maximum penalty from $\$ 2,500$ to $\$ 10,000$. Food, Conservation, and Energy Act of 2008, Pub. L. No. 110-246, § 14214, 122 Stat. 1651, 2228 (codified at 7 U.S.C. $\$ 2149$ (b) (2012)); see, e.g., Letter from U.S. Dep't of Agric. Animal \& Plant Health Inspection Serv. to S. Glenice Viken, S G Kennels (Mar. 22, 2011). This problem seems to have been corrected by 2014 .

181 See 2014 OIG AUDIT REPORT, supra note 133, at 24 n.56 ("[V]iolations cited in a previous inspection report or Official Warnings issued for violations are not considered as prior history.").

1822005 OIG AUDIT REPORT, supra note 169, at 2.

1832014 OIG AUDIT REPORT, supra note 133, at 1-2.

${ }^{184}$ Response to APHIS FOIA Request Regarding Teachable Moments, supra note 169, at 70 .

185 Animal \& Plant Health Inspection Serv., IES Frequently Asked Questions, U.S. DEP'T AGRIC., https://www.aphis.usda.gov/aphis/ourfocus/business-services/ies/ies_faq [https://permacc/GG9J-TBC9] (last modified May 24, 2017). 
Inspector General has repeatedly criticized the agency for discounting stipulated penalties so steeply that they are treated as a "cost of doing business" by the regulated community. ${ }^{186}$

Settlement discounts are calculated using a penalty worksheet that provides for discounts based on the statutorily delineated penalty factors ("size of the business of the person involved, the gravity of the violation, the person's good faith, and the history of previous violations"187). Beyond the fact that these four factors are weighed, "the penalty assessment process is wholly unknown" to the public. ${ }^{188}$ The USDA has insisted on keeping the penalty worksheets secret on

186 See 2014 OIG AUDIT REPORT, supra note 133, at prefatory note (What OIG Found) ("IES issued penalties that were reduced by an average of 86[\%] from Animal Welfare Act's (AWA) authorized maximum penalty per violation [and] under-assessed penalties ... by granting good-faith reductions without merit or using a smaller number of violations than the actual number."); id. at $18 \& \mathrm{n} .41$ ("In three prior OIG audits, we reported that IES' enforcement of AWA was ineffective and the penalty worksheet calculated minimal penalties that did not deter violators."); id. at $3 \&$ n.8 ("In 1995, an Office of Inspector General (OIG) audit of APHIS' enforcement policies found that APHIS did not fully address problems disclosed in a prior report, and that APHIS needed to take stronger enforcement actions to correct serious or repeat violations of AWA. Dealers and other facilities had little incentive to comply with AWA because monetary penalties were, in some cases, arbitrarily reduced and often so low that violators regarded them as a cost of doing business." (footnote omitted) (citing 1995 OIG AUDIT REPORT, supra note 130)); id. at 3 \& n.9 ("In 2005, OIG performed an audit on animals in research facilities and found that APHIS was not aggressively pursuing enforcement actions against violators of AWA and was assessing minimal monetary penalties. Inspectors believed the lack of enforcement action undermined their credibility and authority to enforce AWA. In addition to reducing the penalty by 75 [\%], APHIS offered other concessions - making penalties basically meaningless. Violators continued to consider the monetary stipulation as a normal cost of business, rather than a deterrent for violating the law." (footnote omitted) (citing 2005 OIG AUDIT REPORT, supra note 169)); id. at 3 \& n. 10 ("In 2010, an OIG audit of problematic dealers found that APHIS' enforcement process was ineffective, and the agency was misusing its own guidelines to lower penalties for AWA violators. The agency relied on education to improve dealer compliance, but did not implement an appropriate level of enforcement. At a time when Congress [quadrupled] the authorized maximum penalty to strengthen fines for violations, actual penalties were 20[\%] less than previous calculations." (footnote omitted) (citing 2010 OIG AUDIT REPORT, supra note 141)).

1877 U.S.C. $\$ 2149$ (b) (2012).

188 Letter from Kevin Shea, Adm'r, Animal \& Plant Health Inspection Serv., U.S. Dep't of Agric., to Andrew D. Cardon, Dir. of State \& Legal Affairs, Nat'l Ass'n for Biomedical Research (June 30, 2014) [hereinafter Letter from Kevin Shea to Andrew D. Cardon] (on file with Ohio State Law Journal). Some information about the penalty worksheets has been disclosed through inspector general audit reports, though this information may no longer be current as the penalty worksheets have since been revised. For example, according to the December 2014 audit report:

A settlement adjustment reduces penalties by $75[\%]$ as an incentive for violators to forgo their right to a hearing, thereby saving the agency the associated costs. The discretionary reduction allows IES to recommend an upward or downward change in the penalty up 
the grounds that disclosure would "result in a grave risk of circumvention of the AWA" by "allow[ing] licensees to calculate the cost of doing business with certain AWA violations and to circumvent penalty assessment."189 Legislation was previously introduced to require disclosure of the AWA penalty worksheets but went nowhere. ${ }^{190}$

The USDA's OIG has repeatedly found problems with the agency's penalty worksheets, concluding that they calculate penalties that are too low to have a deterrent effect. ${ }^{191}$ In its 2014 audit, the OIG found that despite repeated revisions to the penalty worksheet intended to better assess penalties, "total monetary penalties were lower than those calculated by prior worksheets."192 Specifically, the OIG found that, in cases involving animal deaths and other "egregious" violations, the USDA had issued penalties to violators that were reduced by an average of $86 \%$ from AWA's authorized maximum penalty. ${ }^{193}$ Following this most recent audit the USDA agreed to again revise its penalty worksheet, but stipulated penalty reductions appear to continue to be exceedingly high.

The USDA has also faced criticism from the OIG for failing to collect stipulated penalties. ${ }^{194}$ The AWA mandates that

Upon any failure to pay the penalty assessed by a final order under this section, the Secretary shall request the Attorney General to institute a civil action in a district court of the United States or other United States court for any district

to $30[\%]$, if IES or AC believes that the monetary penalty calculated by the penalty worksheet is not appropriate.

2014 OIG AUDIT REPORT, supra note 133, at 17-18, 18 n.39. "Good faith may reduce the total penalty by $25[\%]$." Id. at 24 . "Criteria that constitute good faith include complying with AWA and correcting violations, having animals that are in good health and do not suffer as a result of the violations, and cooperating with APHIS." Id. "Guidelines also state that a good faith reduction must not be applied if the violator received a warning within the past 3 years." Id. at 25 .

${ }^{189}$ Letter from Kevin Shea to Andrew D. Cardon, supra note 188, at 3.

${ }^{190}$ Enforcement Transparency Act of 2015, H.R. 3136, 114th Cong.

191 See 2014 OIG AUDIT REPORT, supra note 133, at 18 ("In three prior OIG audits, we reported that IES' enforcement of AWA was ineffective and the penalty worksheet calculated minimal penalties that did not deter violators." (first citing 1995 OIG AUDIT REPORT, supra note 130; then citing 2005 OIG AUDIT REPORT, supra note 169; and then citing 2010 OIG AUDIT REPORT, supra note 141)).

$192 \mathrm{Id}$. at 16.
$193 \mathrm{Id}$.

194 See 1995 OIG AUDIT REPORT, supra note 130, at 18 ("APHIS did not always take appropriate administrative action when violators of the Animal Welfare Act did not pay the penalties established by stipulation agreements.... Unless APHIS is prepared to take aggressive collection action against facilities who do not pay stipulations on a timely basis, the effectiveness of stipulation agreements as an enforcement tool could be reduced."); see also 2010 OIG AUDIT REPORT, supra note 141, at 30-36 (detailing collection failures, including failure to refer delinquent accounts to the Department of Treasury as required by the Debt Collection Improvement Act). 
in which such person is found or resides or transacts business, to collect the penalty, and such court shall have jurisdiction to hear and decide any such action. 195

Such civil actions are virtually unheard of, and it appears that the USDA is not referring uncollected penalties to the Attorney General as required by law. ${ }^{196}$

Nonmonetary settlements are rare ${ }^{197}$ but do occur. Such settlement offers typically involve an "alleged violator's agreement to specific terms that generally involve abstaining from APHIS-regulated activities," such as agreeing to license revocation and/or transfer of animals. 198

\section{c. Formal Administrative Proceedings}

If IES refers a case to the OGC, the OGC may file a formal complaint with an administrative law judge. ${ }^{199}$ Although not required by statute, under current USDA regulations the alleged violator is then given a full, on-the-record hearing before an administrative law judge (ALJ). ${ }^{200}$

After conducting a hearing, the ALJ issues a decision. If he or she agrees that violations have occurred, the decision will delineate the penalty, which can include fines, cease-and-desist orders, and, in the case of entities other than research facilities and carriers, license suspension or revocation. ${ }^{201}$ An adverse decision can be appealed to the USDA's Judicial Officer, and then to a U.S. Court of Appeals. 202

1957 U.S.C. $\S 2149$ (b) (2012).

${ }^{196} \mathrm{~A}$ response to an FOIA request submitted to the DOJ for such referrals yielded a response that "no records responsive to your request were located." Letter from Vanessa R. Brinkman to author, supra note 168 . The author is still awaiting a response to a similar request submitted to the USDA in June 2016.

197 For example, in calendar year 2011 there was only one such settlement.

198 Animal \& Plant Health Inspection Serv., supra note 185.

199 Of course, the OGC is not required to do so and in many cases it does not, even where Investigative and Enforcement Services urges enforcement action. See Animal \& Plant Health Inspection Serv., Enforcement Glossary, U.S. DEP'T AGRIC., https:/www.aphis.usda.gov/aphis/ourfocus/business-services/

ies/ies_performance_metrics/ies_enforcement_glossary [https://perma.cc/8L5B-T6XQ] (last modified May 4, 2017) ("After IES refers a case and supporting evidence to USDA's Office of the General Counsel (OGC) with a request to institute an administrative proceeding, OGC reviews the evidence to determine whether there is reason to believe a violation of an APHISadministered law has occurred. If so, OGC prepares an administrative complaint that it files on behalf of APHIS to institute a formal adjudicatory administrative proceeding.").

200 See supra notes $124,156-57$ and accompanying text.

${ }^{201}$ Notably, despite APHIS's attempts to defend its severe penalty discounting by claiming that penalties issued by administrative law judges are severely reduced, the OIG has rejected this. 2014 OIG AUDIT REPORT, supra note 133, at 16-21.

2027 U.S.C. $\S 2149$ (c); 7 C.F.R. $§ 1.145$ (2010). 


\section{d. Judicial Enforcement}

As noted above, although the AWA provides for referral to the Attorney General for criminal penalties and injunctive relief, such actions are virtually unheard of and the USDA appears to be violating the mandate that it refer to the Attorney General cases involving violations that place the health of an animal in serious danger or where an entity is dealing in stolen animals. ${ }^{203}$ Approximately five years ago, the USDA announced plans to partner with the Department of Justice on AWA enforcement actions, but to date no specific details of such a plan have been announced.

Having detailed the purposes, scope, and implementation of the AWA, the Article now turns to a case study of the predominant enforcement mechanism used under the Act, official warnings, to assess its efficacy in promoting compliance with the law.

\section{CASE Study: ANimal Welfare Act Warnings AND RecidivisM}

\section{A. Background and Methodology}

Warnings are by far the most commonly utilized enforcement action under the AWA, consistently comprising more than half of all AWA enforcement actions. In fiscal year 2017, more than $90 \%$ of all enforcement actions taken under the AWA were warnings. ${ }^{204}$ Eighty-eight percent of the remaining enforcement actions were settlement agreements, while $12 \%$ were formal administrative complaints. ${ }^{205}$

203 See supra note 164 and accompanying text.

204 See Animal \& Plant Health Inspection Serv., supra note 16.

${ }^{205}$ Id. (reporting fourteen settlements (one nonmonetary and thirteen monetary) and two formal administrative complaints in fiscal year 2017). 
Figure 2: IIhstration of the Breakdown of AWA Enforcenent Actions in Fiscal Year 2017

\section{Warnings \\ 㽬 Settlement Agreements Dormal Complaints}

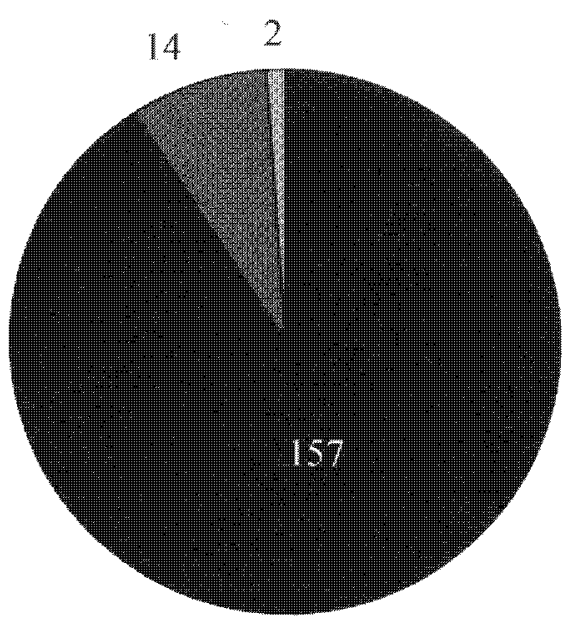

The USDA considers warnings to serve as an "immediate deterrent," states that issuance of a warning "allows APHIS to address infractions in a timely manner, and facilities to improve their overall compliance before further action is necessary. "207

This case study assesses the effectiveness of AWA wamings as a deterrent by examining recidivism of facilities after receiving them. The study examines the compliance behavior of all facilities that received official warnings in calendar year 2011 and continued to be inspected by the USDA thereafter. 208 I examined reports of inspections following issuance of the warning to assess whether the receipt of a warning motivated compliance behavior. The year 2011 was chosen because it affords a significant window of subsequent regulated activity and sufficient inspection data to allow for a meaningful analysis of subsequent compliance behavior. 209

2062015 EXPLANATORY NoTES, supra note 16, at 20-50; see also Cardon et al., supra note 173, at 13 ("[Official Warnings] may be issued with or without an investigation by IES.").

2072015 EXPLANATORY NOTES, supro note 16, at 20-108.

208 Thus, facilities that were no longer regulated by the USDA at the time of data compilation, such as those who had voluntarily cancelled their licenses (the vast majority of this category), were not included in the analysis.

209 Among other things, this window mitigates against bias resulting from reversion to the mean. As Shimshack and Alm explain,

Enforcement actions... will always follow periods of noncompliance.... so compliance may be higher... after interventions as plants simply return to their average performance steady state. Mean reversion may bias relationships between... noncompliance and regulator interventions in a negative direction, suggesting that regulator actions are more effective than they really are. 
To determine the extent to which warnings might constitute a credible threat, the case study also analyzes the frequency and severity of subsequent enforcement actions faced by those who continued to violate the law after receiving warnings. Thus, I searched all AWA enforcement documents published by the USDA to ascertain whether those who received warnings in 2011 subsequently faced enforcement actions of any sort. For those that faced subsequent monetary penalties, I also calculated and compared the actual final penalty and the potential statutory maximum penalty.

\section{B. Case Study Findings}

\section{Rates, Types, and Examples of Recidivism}

The data set of all entities that received warnings in calendar year 2011 and continued to operate under the same license as of March 2016, when the data was compiled, included a total of eighty-nine entities. Analysis of the compiled data revealed that a facility that had previously received a warning was more likely to commit six or more subsequent violations than it was to commit zero to one, with a significant percentage $-38.5 \%$ of those facilities that received warnings-going on to commit six or more subsequent violations. Moreover, nearly half of the warned facilities- $-48.3 \%$-went on to violate one or more of the specific regulatory subsections for which they previously received a warning for violating.

In one particularly egregious example, a Minnesota dog breeding facility, S G Kennels, received a warning in 2011 for violating three different AWA standards, including the requirement for adequate veterinary care. ${ }^{210}$ According to available inspection reports, the facility was cited during every single subsequent inspection for repeatedly failing to provide adequate veterinary care to dogs. ${ }^{211}$ Similarly, a Kansas dog breeder, after receiving a warning for failing to comply with six AWA requirements, including the veterinary care

James Alm \& Jay Shimshack, Environmental Enforcement and Compliance: Lessons from Pollution, Safety, and Tax Settings, 10 Found. \& TRENDS MicroeCON. 209, 229 (2014).

210 See Animal \& Plant Health Inspection Serv., U.S. Dep't of Agric., Official Warning of S. Glenice Viken, S G Kennels (2011); see also 9 C.F.R. $\S 2.40(\mathrm{~b})$ (2017) (veterinary care requirement).

211 See Animal \& Plant Health Inspection Serv., U.S. Dep't of Agric., Inspection Reports of S. Glenice Viken, S G Kennels (Sept. 21, 2016; July 6, 2016; Apr. 19, 2016; Feb. 10, 2016; Dec. 1, 2015; Sept. 9, 2015; June 16, 2015; June 15, 2015; A pr. 9, 2015; Apr. 1, 2015; Jan. 15, 2015; Oct. 6, 2014; Nov. 14, 2013). 
requirement, ${ }^{212}$ also went on to be cited repeatedly for violations, including five more times for inadequate veterinary care. ${ }^{213}$

Another facility, The Gorilla Foundation, where Koko the famous signing gorilla is held, had a similar pattern of subsequent violations. After receiving an official warning in 2011 for repeatedly violating the requirement that surfaces that cannot readily be cleaned be replaced when worn or soiled, 214 The Gorilla Foundation proceeded to violate this same requirement at least seven more times. ${ }^{215}$ Indeed, during every subsequent full inspection, the facility was found in violation of the requirement. ${ }^{216}$

Also concerning were a number of facilities that, after receiving a warning for failing to be available to be inspected, ${ }^{217}$ continued to be cited for the same. ${ }^{218}$ These facilities went for prolonged periods without being inspected, despite their history of noncompliance, and thus were able to evade regulatory oversight, which the USDA considers a critical violation. ${ }^{219}$

The number of previously warned facilities that were cited for direct violations - those that are likely to impact the well-being of animals - was also alarming. More than one-quarter of the facilities in the case study ${ }^{220}$ were cited for one or more direct violations after receiving a warning. An even higher number-thirty-seven, or $41.6 \%$-were subsequently cited for one or more

212 See Animal \& Plant Health Inspection Serv., U.S. Dep't of Agric., Official Warning of Charlene and Darlene Koster (Sept. 8, 2011).

213 See Animal \& Plant Health Inspection Serv., U.S. Dep't of Agric., Inspection Reports of Charlene and Darlene Koster (June 22, 2015; Mar. 2, 2015; Aug. 11, 2014; Dec. 13, 2014; June 20, 2013).

214 Animal \& Plant Health Inspection Serv., U.S. Dep't of Agric., Official Warning of The Gorilla Foundation (Aug. 3, 2011); see also 9 C.F.R. § 3.75(c)(2).

215 Animal \& Plant Health Inspection Serv., U.S. Dep't of Agric., Inspection Reports of The Gorilla Foundation (Dec. 4, 2015; June 17, 2015; Mar. 26, 2015; Dec. 18, 2014; Aug. 20, 2014; Mar. 11, 2014; Dec. 17, 2013) [hereinafter Inspection Reports of The Gorilla Foundation]. The facility was not cited during the USDA's August 6, 2015 or September 24, 2013 inspections for violating this provision, but both of those inspections were focused inspections. See Animal \& Plant Health Inspection Serv., U.S. Dep't of Agric., Inspection Report of The Gorilla Foundation (Aug. 6, 2015); Animal \& Plant Health Inspection Serv., U.S. Dep't of Agric., Inspection Report of The Gorilla Foundation (Sept. 24, 2013); see also supra note 140 and accompanying text (explaining focused inspections).

216 See Inspection Reports of The Gorilla Foundation, supra note 215.

217 See, e.g., Animal \& Plant Health Inspection Serv., U.S. Dep't of Agric., Official Warning of Denise Dickelman (Aug. 22, 2011); Animal \& Plant Health Inspection Serv., U.S. Dep't of Agric., Official Warning of Byron and Loretta Johnson, Grandpa Nicks Petting Farm (2011).

218 See Animal \& Plant Health Inspection Serv., U.S. Dep't of Agric., Inspection Reports of Denise Dickelman (Feb. 22, 2016; Dec. 9, 2015; Oct. 28, 2015); Animal \& Plant Health Inspection Serv., U.S. Dep't of Agric., Inspection Reports of Byron and Loretta Johnson, Grandpa Nick's Petting Farm (Nov. 24, 2015; Jan. 29, 2014; Sept. 18, 2013).

219 See supra note 153 and accompanying text.

${ }^{220}$ Twenty-three out of eighty-nine, or $25.8 \%$. 
repeat violations. ${ }^{221}$ Because the "critical" violation designation was only recently adopted by the USDA and has not yet been incorporated into the agency's inspection guide, citations for critical violations following receipt of a warning was not assessed for this case study but should be considered in any future studies.

The case study revealed that a high number of facilities that received warnings in 2011 for AWA violations have continued to violate the Act, including, in many cases, the very same provisions for which they received warnings for previously violating. Because this finding suggests that warnings are not acting as a deterrent in a high proportion of cases, indicating that the regulated community may not perceive the warnings as a credible threat, ${ }^{222}$ the next Subpart looks at the rate and severity of subsequent enforcement action faced by those facilities that continued to violate the AWA after receiving a warning.

\section{Subsequent Enforcement Actions}

Of the seventy-seven facilities in the data set that violated the AWA at least once after receiving a warning $(86.5 \%$ of the total), thirty-four $(44.2 \%)$ have faced some sort of subsequent enforcement action. Some facilities faced more than one type of subsequent enforcement action. Of those subsequent enforcement actions, more than half were warnings - including a dog dealer that received two subsequent warnings ${ }^{223}$ (and has continued to violate the AWA since receiving the third warning ${ }^{224}$ ). The breakdown of the subsequent enforcement actions is shown in Figure 3 below. ${ }^{225}$

Notably, more than $60 \%$ of the subsequently issued warnings were issued within three years of the prior (2011) warning, 226 in contravention of the USDA's stated policy that a facility does not qualify for a warning if it has faced another enforcement action within three years 227 - thus further diluting the credibility of the agency's warnings.

221 Again, repeat violations are violations of the same regulatory subsection in two sequential inspections. See ANIMAL WELFARE INSPECTION GUIDE, supra note 143, at 2-8; see also supra text accompanying note 143.

222 See supra Part II.

223 See Animal \& Plant Health Inspection Serv., U.S. Dep't of Agric., Official Warnings of Lynn Sartin (Jan. 9, 2015; Aug. 5, 2014; Mar. 3, 2011).

224 See Animal \& Plant Health Inspection Serv., U.S. Dep't of Agric., Inspection Reports of Lynn Sartin (June 2, 2015; Feb. 24, 2015; Jan. 26, 2015; Dec. 4, 2014; Aug. 27, 2014; Aug. 20, 2014; Aug. 13, 2014; May 9, 2014; May 8, 2014; May 7, 2014).

${ }^{225}$ See, e.g., U.S. Dep't of Agric. Animal \& Plant Health Inspection Serv., Citation and Notification of Penalty to David and Joane Cline (Feb. 28, 2013) (assessing a penalty of $\$ 2,786$ for sixteen violations on four dates impacting dozens of animals).

226 Sixteen out of twenty-six.

227 ANIMAL \& Plant HEALTH InSPECTION SERV.: ANimAl CARE, supra note 170, at 12. 
Figure 3: Subsequent Enforcement Actions Faced by Recidivists

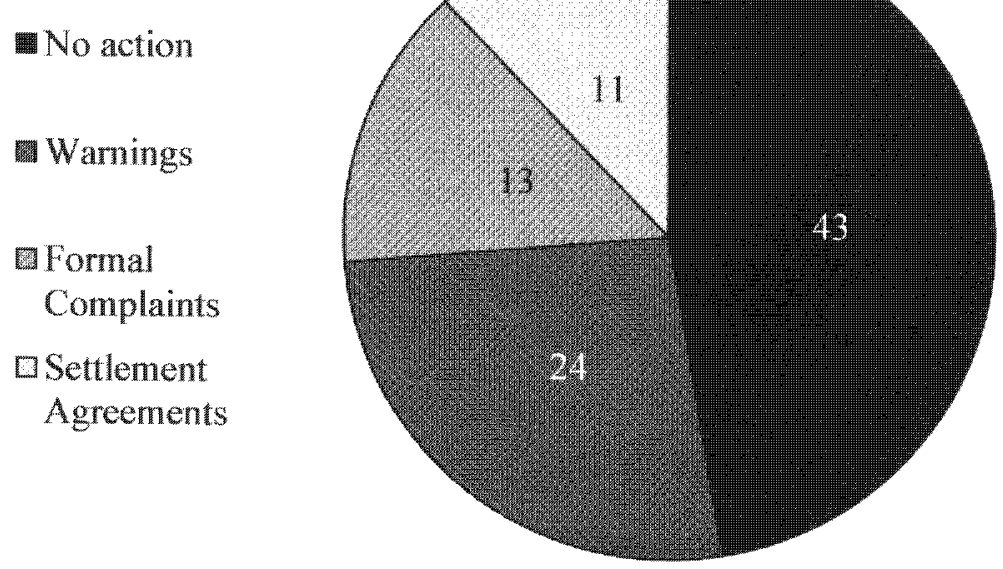

To further assess the credibility of the threat contained in the warnings, the extent to which potential penalties were reduced in settlement agreements was analyzed. If penalties are not likely to be significant, a warning is less likely to incentivize compliance behavior. ${ }^{228}$ As noted above in Part III, the USDA Office of Inspector General has repeatedly criticized the agency for severely discounting penalties in settlement agreements.

Consistent with the OIG reports, I found that the penalties included in settlement agreements were consistently severely discounted. In fact, I found higher discounting than that documented in any of the OIG reports, a surprising result given that my data set was comprised exclusively of entities that had faced a prior enforcement action (the warning) and thus presumably would have been less likely to qualify for penalty discounts based on at least two of the four statutory factors good faith and history of previous violations. ${ }^{229}$ Despite the consistent history of previous violations in my case study, the average discount rate i.e., the reduction from the maximum statutory penalty-for those that entered into settlement agreements was $96.4 \%$. The lowest discount rate was $85 \%$

On the whole, it appears that official warnings are failing to deter future violations in a large proportion of cases and that the reason for this may be that the threat of future enforcement is not credible. Drawing on the scholarship on enforcement approaches and warnings discussed in Par II, Part V analyzes these empirical findings and their implications, both for the AWA specifically and for 
administrative warnings more generally. It also makes recommendations for both policy changes and further research.

\section{IMPLICATIONS AND RECOMMENDATIONS}

\section{A. Making Administrative Warnings Credible}

Given the limited nature of the USDA's escalation of penalties in the face of continued AWA violations - in terms of both penalty frequency and size - it is not surprising that warnings appear to be largely failing to incentivize compliance. In Ayres and Braithwaite's words, the USDA has put itself in a "situation where their implied plea to 'cooperate or else' has little credibility." 230 But this does not have to be the case.

Unlike many agencies that have limited enforcement options and thus encounter difficulties in trying to design an enforcement pyramid and escalate penalties, ${ }^{231}$ the USDA has an array of enforcement options under the Animal Welfare Act, as discussed in Part III. Indeed, the agency has at its disposal all of the enforcement actions included in Ayres and Braithwaite's enforcement pyramid-persuasion, warnings, civil monetary penalties, criminal prosecution, license suspension, and license revocation ${ }^{232}$ - as well as additional options, including cease-and-desist orders (and additional penalties for violating them) and injunctive relief. ${ }^{233}$ However, as noted above, the USDA is not currently taking advantage of all of these options —criminal penalties are virtually never sought, and there is no indication that injunctive relief has ever been sought in the more than fifty-year history of the Act. Moreover, it appears that the agency is likely over-relying on certain enforcement mechanisms-particularly warnings, and also possibly discounted stipulated penalties-while underutilizing others. Thus, even in the face of repeated noncompliance and disregard of warnings, it is rare for the agency to escalate penalties. And even when the USDA escalates to monetary penalties, as the OIG has repeatedly noted, the penalties are severely discounted-and sometimes go uncollectedundermining any deterrent effect they might have. ${ }^{234}$

Synthesizing these findings with the scholarship discussed in Part II provides a clear path for the USDA-and other agencies - to follow to likely enhance compliance by repeat violators. Specifically, the agency should first:

${ }^{230}$ AYRES \& BRAITHWAITE, supra note 70, at 36; see also Lochner \& Cain, supra note 77 , at 1901-02 ("[T] he ability ... to impose-or threaten to impose-a variety of enforcement sanctions... ensur[es] that the [regulatory] agency is not forced to choose between low-cost, low-impact remediation and high-cost, high-impact criminal sanctions."). See generally supra Part II.

231 See AYRES \& BRAITHWATTE, supra note 70, at 36.

232 Id. at 35-36; see also supra Figure 1.

233 See supra Part III.

234 See supra Part III. 
(1) Set and follow a clear rubric for escalating penalties when entities that have received warnings continue to violate the law; and

(2) Revise the stipulated penalty guidelines to ensure higher and more meaningful civil penalty settlements.

The importance of this second point cannot be overemphasized. As discussed in Part III, excessive discounting of civil penalties under the AWA is a longstanding problem. Moreover, there is some empirical analysis supporting the proposition that imposing a fine that is too low can actually have more detrimental effects on compliance than imposing no fine at all. ${ }^{235}$

Over time, the literature suggests that these two steps alone should render warnings more credible and thus effective in inducing compliance. Thus, while it might call for a higher number of civil penalties at the outset, the long-term effect should be to enhance compliance overall and thereby reduce the need for penalty escalation. Given the paucity of empirical research testing the theoretical literature, however, the agency would be well-advised to carefully monitor and assess the effects of such changes.

While these two changes are likely to enhance compliance, they will not yield perfect compliance and there will still be repeat offenders who, even in the face of more meaningful monetary penalties, remain undeterred. When these entities persist in violating the AWA, it is important that the USDA not "[1]op the top[] off the enforcement pyramid[]"236_i.e., that it continue to escalate up the pyramid. Thus, in addition to the measures suggested above, to enhance AWA compliance and reduce the number of chronic violators, the USDA should utilize its authority in selected cases to seek criminal prosecution. This likely means building a strong partnership with the Department of Justice. By virtually never utilizing the AWA's criminal enforcement provision, the agency has undermined its ability to obtain compliance. Indeed, while Ayres and Braithwaite put criminal penalties lower down on the enforcement pyramid than license revocation and deems the latter "corporate capital punishment,"237 recent examples of individuals who have continued to violate the AWA even after permanent revocation of their licenses suggest that criminal penalties may

${ }^{235}$ See Faure, supra note 59, at 326-27 ("[F]ining a polluter with too low a fine can have a perverse learning effect: firms will then be informed about the low expected sanction, whereas those who were not confronted with these low sanctions may still wrongly believe that expected sanctions are higher than they actually are and thus be more induced towards compliance. The policy implication seems to be that if the agency or court decides to fine a polluter it is better not to impose any fine at all than one too low, since otherwise one would destroy wrong, subjective perceptions of potential perpetrators that fines are higher than they actually are." (footnote omitted) (citing Sandra Rousseau, The Impact of Sanctions and Inspections on Firms' Environmental Compliance Decisions 17, 19 (Katholieke Universiteit Leuven, Ctr. for Econ. Studies, Working Paper No. 2007-04, 2007))).

236 AYRES \& BRAITHWAITE, supra note 70, at 38-39.

${ }^{237}$ Id. at 53. 
be the only means of incapacitating the worst violators. ${ }^{238}$ It is also worth noting that seeking criminal penalties through judicial enforcement, which has a higher profile than administrative actions and, especially, settlement decisions, may have a greater general deterrent effect. In the environmental context, Richard $\mathrm{H}$. Rosenberg has suggested that a focus on a "stealth system" of "administrative enforcement emphasizing negotiated settlements and relatively low civil penalties may provide the regulated community with the idea that ... enforcement does not present a serious threat of court enforcement, and so may not deter noncompliant conduct." 239

Finally, the USDA should more consistently seek license suspension or revocation for those entities that remain undeterred by lesser penalties. As noted above, it may be desirable to seek such actions prior to escalating to criminal enforcement. Because the agency has expressed reticence to seek license penalties because of the resource intensity and time delays in pursuing full, onthe-record hearings, it may also wish to explore the possibility of following in the footsteps of the many agencies that have moved toward more efficient informal hearing practices that still protect due process interests. ${ }^{240}$

\section{B. Accounting for Publicity Effects}

One issue that warrants serious further consideration is the extent to which, perhaps even without increasing the credibility of warnings, publicity effects might, in some cases, suffice to induce compliance. As discussed in Part III, Kagan et al. have identified "reputational concerns" as one of three key motivators of compliance. ${ }^{241}$ They note that pressures from those with the potential to "generate adverse publicity"-such as the media and advocacy groups-are the primary drivers here. ${ }^{242}$ Other scholars have also elaborated on the role of publicity in motivating compliance. Given that, as the USDA has recently noted, "[t]he welfare of animals nationwide continues to attract significant media attention and passionate public engagement"243 - and given the current and historical strong public interest in animal welfare 244 - it is possible that publicity effects might be particularly strong in the AWA context.

${ }^{238}$ See, e.g., Lancelot Kollman Ramos, 74 Agric. Dec. 292, 311-12 (U.S.D.A. 2015); In re Karl Mitchell, AWA Docket No. 09-0084, at 6-12 (U.S.D.A. Dec. 21, 2010) (decision and order).

${ }^{239}$ Ronald H. Rosenberg, Doing More or Doing Less for the Environment: Shedding Light on EPA's Stealth Method of Environmental Enforcement, 35 B.C. ENVTL. AFF. L. REV. 175,215 (2008).

240 As noted above, the AWA does not mandate full, on-the-record hearings, but the agency has provided for them through regulation. For a complete discussion of the USDA's rules of practice, the overall trend toward more informal administrative hearing processes, and some modifications the USDA might make, see Winders, supra note 127.

${ }^{241}$ Kagan et al., supra note 63, at 55 n.2.

242 See id. at 42.

2432015 EXPLANATORY NOTES, supra note 16, at 20-127.

${ }^{244}$ See supra notes $17-21,25$ and accompanying text. 
Until recently the USDA posted official warnings (and other enforcement actions) online and appeared to consider such publication as a deterrent factor ${ }^{245}$ - but generally did not more actively publicize them. Increasingly, however, animal advocacy groups and media outlets had begun to draw attention to these actions. It would be worthwhile to conduct empirical research on the effects of such publicity, including comparative analyses of subsequent compliance in cases where enforcement was publicized and in cases where it was not, and qualitative research in the form of interviews with regulated entities to develop a sense of the degree to which they are motivated by the possibility of adverse publicity. Because "the literature is mixed as to when in the legal process reputational damage is most salient (notice of pending charges, case announcement, processing, or case resolution)" and as to the relative effects of civil, criminal, and regulatory actions, ${ }^{246}$ if it is possible to collect sufficient data it also would be useful to compare the impacts of publicity arising from different types of enforcement actions and at different stages of enforcement. Given that, in the AWA context, sometimes mere citations also generate negative publicity, it would also help to compare the publicity effects of citations against those of warnings to see if the latter do any additional work.

In addition, the USDA might significantly enhance compliance by assigning a "score" to regulated entities based on AWA inspection report results and enforcement actions and requiring those entities to disclose that score at points of sale.

Readily disclosing inspection and enforcement information on its website, as it did until recently, is an important first step (and one that appears to be required by the Freedom of Information Act), ${ }^{247}$ as it has allowed highly motivated consumers and intermediaries such as animal advocacy groups and investigative reporters to access and distribute such information. However, the literature on targeted transparency suggests that disclosure might be rendered much more effective by making this information available not only on a website that takes a certain level of investment and sophistication to use, but by also making it readily available to consumers in a comprehensible way at the time and place that they make purchasing decisions. ${ }^{248}$

Here, restaurant hygiene grading might serve as a model. As experts in targeted transparency as a regulatory mechanism Archon Fung, Mary Graham, and David Weil have noted, the window-front restaurant hygiene grades that have become so familiar have proven highly effective, yielding "measurable

245 See 2015 EXPLANATORY NOTES, supra note 16, at 20-50 ("APHIS exercises immediate deterrent options, such as letters of warning and the publication of such letters on the internet.").

246 Simpson et al., supra note 67, at 238-39.

247 See Winders, supra note 17.

248 ARCHON FUNG ET AL., FULL DisClOSURE 56-57 (2007) ("Information must ... be compatible with the usual ways that people go about making their decisions. ... Compatibility ordinarily includes two elements: format and time and place of availability."). 
increases in hygiene quality and a consequent significant drop in hospitalizations from food-related illnesses" as well as "revenue increases for restaurants with high grades and revenue decreases for C-graded restaurants."249 The reason for this success is attributed largely to two factors: First, "everyone who attended grade school understands the meaning of A, B, and C letter grades," and second "because grades are posted at the entrance of every restaurant, they are available to patrons when and where they make dining decisions." 250

Mandated disclosure of an animal welfare "grade" or "score" might have similar effects and is worth further consideration. Indeed, there is some preliminary precedent for such efforts. Following concerns raised by the Office of Inspector General, the USDA began requiring regulated entities to publicly post their licenses so that the public could ensure that the facility was currently licensed. However, given that possession of an AWA license says nothing about compliance (because of the USDA's policy of automatically renewing licenses regardless of violations ${ }^{251}$ ), the meaningfulness of this disclosure is highly circumscribed. Perhaps more usefully, some jurisdictions have begun requiring those selling dogs and cats from AWA regulated entities to display "cage tags" revealing information about the entity supplying the animals. With the website blackout, however, such laws have become virtually unenforceable. In addition, such efforts have not utilized a clear grading or scoring system that makes the information readily comprehensible and useful to consumers. Moreover, even when inspection reports were readily available online, the presence of middlemen in the wholesale pet industry posed difficulties for disclosure efforts, suggesting that targeted disclosure may work better for some categories of AWA-regulated entities-such as public-facing exhibitors like zoos-than others.

\section{Implications for Other Administrative Regimes}

This Article has found that warnings are heavily relied on to enforce the Animal Welfare Act but appear to be largely ineffective in incentivizing compliance, rendering the USDA's reliance on them problematic. Given the heavy reliance on warnings across agencies, and the paucity of empirical research on their effectiveness, ${ }^{252}$ it is highly unlikely that the AWA example is aberrant.

Indeed, what data is available suggests that, like the USDA in the Animal Welfare Act context, other agencies that rely on warnings are also failing to

$249 \mathrm{Id}$. at 83.

$250 \mathrm{Id}$. at 56-57; see also Oren Bar-Gill, Defending (Smart) Disclosure: A Comment on More than You Wanted To Know, 11 JeRuSALEM REV. Legal STUD. 75, 76 (2015) (" $[S]$ implification using 'scores'] contexts.").

${ }^{251}$ See supra note 127 and accompanying text.

${ }^{252}$ See supra Part II. 
escalate penalties when their warnings go unheeded. A review of state and local enforcement of air and water quality regulations in the United States found that the vast majority of notices of violations never resulted in penalties, and even in the few instances where penalties were imposed, they were "very small." 253 In 2009 , only $5.65 \%$ of entities that received warnings or notices of violation from the Ohio EPA's surface water division were subjected to a formal enforcement action. ${ }^{254}$ While it is possible that escalated penalties are few and far between because the warnings are in fact incentivizing compliance, it seems unlikely based on the literature and the available information and, at a minimum, warrants further study.

In other contexts, it appears that agencies may not even be following up on warnings to assess for subsequent compliance. For example, warning letters sent by the Food and Drug Administration state that the recipient must provide proof of corrective action, and a close-out letter "may issue when, based on FDA's evaluation, the firm has taken corrective action to address the violations contained in the Warning Letter," 255 but "[f]or all Warning Letters sent, a small percentage have been 'closed out' according to the FDA's database and an even smaller percentage have letters of response from the responsible business." 256 In addition, searches of the FDA's tobacco retailer compliance check database suggest that a huge number of retailers that have received warnings from the agency have not been subsequently inspected. ${ }^{257}$

These are but a few examples. As discussed in Part II, warnings are nearly ubiquitous, relied on across an array of regulatory regimes. In addition to a host of federal agencies, warnings are used by a variety of state agencies and internationally. We know very little about whether or when these warnings motivate compliance. Accordingly, there is a significant need for analysis of

253 Clifford S. Russell et Al., Enforcing Pollution Control LaWs 39 (1986).

254 David Emerman, Note, An Environmental Law Even Judge Learned Hand Would Violate: Ohio EPA Needs Non-Monetary Penalties To Enforce Construction NPDES Permits, 60 CleV. ST. L. REV. 275, 290 nn.147-48 (2012) (citing Enforcement Program, OHIO ENVTL. PROTECTION AGENCY, http:/www.epa.ohio.gov/dsw/enforcement/enf.aspx [https://perma.cc/K4

H2-L5XJ).

255 About Warning and Close-Out Letters, U.S. FOOD \& DRUG ADMIN., http:/www.fda.gov/ICECI/EnforcementActions/WarningLetters/ucm278624.htm [https://perma. cc/3CFQ-LKJN] (last updated Jan. 29, 2018).

256 Jennifer L. Pomeranz, A Comprehensive Strategy to Overhaul FDA Authority for Misleading Food Labels, 39 AM. J.L. \& MED. 617, 633 (2013) (footnote omitted) (citing Warning Letters, U.S. FOOD \& DRUG ADMIN., https://www.fda.gov/ICECI/EnforcementActions/WarningLetters/defaulthtm [https://perma.ce/UF S3-33Y2] (follow "Browse Warning Letters with Response Letters" hyperlink; or follow "Browse Warning Letters with Closeout Letters" hyperlink)) (last updated Apr. 17, 2018) (citing to the FDA website showing lists of Warning Letters that have associated Close-Out Letters or Response Letters).

${ }^{257}$ Compliance Check Inspections of Tobacco Product Retailers, U.S. FOOD \& DRUG ADMIN., http://www.accessdata.fda.gov/scripts/oce/inspections/oce_insp_searching.cfm [https:// perma.cc/Q6TP-J28Z] (last updated May 28, 2018). 
warnings and their efficacy in other administrative contexts. Until such research is conducted, administrative agencies' heavy reliance on warnings is, as Glicksman and Earnhart have cautioned, "more of an act of faith than a rational policy choice." 258

\section{CONCLUSION}

Administrative agencies rely heavily on warnings as an enforcement mechanism, despite the fact that economic models of public enforcement suggest that warnings should have no role in motivating compliance. While alternate enforcement theories, including responsive regulation, suggest that there may be a role for warnings, there has been virtually no analysis of their efficacy.

The literature suggests that warnings might be effective where they are part of an enforcement pyramid, but makes clear that if penalties are not escalated when warnings are disregarded, then agencies are likely to lose credibility and warnings will effectively be rendered meaningless.

This case study of compliance behavior by entities regulated by the U.S. Department of Agriculture under the Federal Animal Welfare Act suggests that warnings are failing to incentivize compliance in a large proportion of cases. Based on the literature, this is likely the result of the USDA's failure to escalate penalties for the majority of entities that continue to violate the law after receiving a warning. The USDA's warnings could likely be rendered more credible - and thus more effective - if the USDA begins to more consistently and meaningfully escalate enforcement in the face of ongoing noncompliance.

These findings, combined with the heavy reliance on warnings across the agencies and the paucity of data on their effectiveness, should serve as a wakeup call to agencies that are blindly relying on warnings. There is a significant need for further research in a variety of contexts if administrative agencies are going to continue to rely on warnings as an enforcement tool.

258 Glicksman \& Earnhart, supra note 60, at 608 n.24. 
